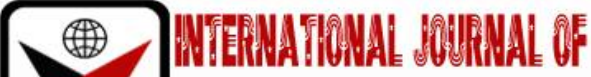

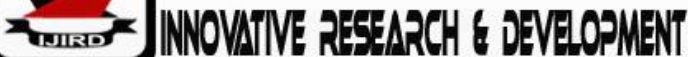

ISSN 2278 - 0211 (Online)

\section{Smallholder Farmers' Perceptions of Climate Change and Adaptation Options for Sustainable Agriculture: Evidence from Itombwe Massif, Eastern DR Congo}

Leonard K. Mubalama
Lecturer, Département of Environment and Sustainable Development/Centre De Recherche
En Gestion De La Biodiversité Et Changement Climatique - CRGBC
ISDR Bukavu, Democratic Republic of Congo
Dieu Merci Masumbuko
ISDR Bukavu, Democratic Republic of Congo
Felix A.Igunzi
Assistant Researcher, Department of Environment and Sustainable Development,
Assistant Researcher, Department of Research and Biomonitoring,
ICCN/ Reserve Naturelle d'Itombwe, Democratic Republic of Congo
Germaine M. Buhendwa
Protected Area Manager, Department of Natural Reserve Coordination,
ICCN/ Reserve Naturelle d'Itombwe, Democratic Republic of Congo
Désiré R. Mweze
Doctoral Student, Department of Economy and Policies of Natural Resources,
University of Antananarivo, Madagascar

\begin{abstract}
:
Climate change affects agriculture and agriculture also affects climate change. Rural farmers, whose livelihoods depend on the use of natural resources, are likely to bear the brunt of adverse impacts. Higher temperatures, reduced rainfall and increased rainfall variability reduce crop yield and threaten food security in Itombwe massif low income and agriculture-based economies. In particular, climate change is expected to intensify existing problems and create new combinations of risks, particularly in Itombwe massif. The situation is made worst due to factor such as widespread poverty, over dependence on rain fed agriculture, inequitable land distribution, limited access to capital and technology, inadequate public infrastructure, such as agricultural service roads, long term weather forecasts and inadequate research and extension. By lessening the severity of key damages to the agricultural sector, adaptation is the key defensive measure. This paper reviews agricultural adaptation strategies employed by farmers in various villages in Itombwe massif in cushioning the effects of climate change. This study explored smallholder farmers' knowledge on perceptions, vulnerability, adaptations and coping strategies, coupled with scientific analysis of the prevailing climatic regimes in the study areas and established enhanced adaptations of the agricultural systems. Lack of modern early warning systems, inflexible cropping calendar and narrow choice of crop varieties should aggravate the climate vulnerability. Hence, improving forecasting and dissemination of climate information, developing drought resistant varieties and promoting farm-level adaptation measures like use adjusting planting dates should be prioritized to improve community resilience to climate change. This study examined farmers' perceptions of long-term climate change, adaptation measures undertaken, and the determinants of adaptation decisions based on household surveys conducted in Itombwe massif. The information accrued from the study is expected to be used by smallholder farmers to strengthen understanding about farmers' decision-making process to enable policymakers and other stakeholders, including scientific communities and policy makers to support adaptation to climate change at the farm-level and address issues related to climate variability and change in similar agro-climatic conditions.
\end{abstract}

Keywords: Adaptation, climate change, crop productivity, Itombwe massif, perception

\section{Introduction}

Climate is a robust determinant of agricultural sector performance and, in turn, general economic performance in the Democratic Republic of Congo (DRC) and elsewhere in rainfed Sub-Saharan Africa (SSA). Agricultural growth and productivity and economic development are intricately linked in SSA. As such, any negative effects of climate change are likely to have undesirable effects on the livelihoods of many communities and economies. Much work has been carried out within the region to determine the effects of climate change on agriculture and related communities and economies. 
However, there is a limited amount of publications that explicitly attend to the various vulnerable communities in the agricultural sector in Africa, i.e., smallholder farmers (crop farmers and pastoralists), women, and youth, collectively, over and above the predicted climate change impacts.

Climate change affects agriculture and agriculture also affects climate change. Higher temperatures, reduced rainfall and increased rainfall variability reduce crop yield and threaten food security in low income and agriculture-based economies (Deressa et al. 2011). Thus, the impact of climate change is detrimental to countries that depend on agriculture as the main livelihood, many located in Tropical Africa (Houghton et al., 2001; IAC, 2004;). Climate change, which is attributable to the natural climate cycle and human activities, has adversely affected agricultural productivity in Africa. There is ample evidence that reveals that Africa and other developing countries face more challenges from climate change because of poor adaptation mechanisms in place (Jagtap, 2007; Nwafor, 2007). Itombwe massif's rural community, too, has been negatively affected by the impacts of climate change. This can be evidenced by the increase in unreliable rainfall patterns, resulting in flash floods and droughts. This has left communities that rely on farming outputs at greater risk, because climate change diminishes the prospects of having a great yield every year. The fact that climate has changed in the past and will continue to change in the future underlines the need to understand how farmers perceive and adapt to climate change. Such information is necessary to guide future adaptation strategies.

Studies indicate that Africa's agriculture is negatively affected by climate change (McCarthy et al. 2001). Adaptation is one of the policy options for reducing the negative impact of climate change (Adger et al. 2003; Kurukulasuriya and Mendelsohn, 2008). Adaptation to climate change refers to adjustment in natural or human systems in response to actual or expected climatic stimuli or their effects, which moderates harm or exploits beneficial opportunities (IPCC, 2001). Common adaptation methods in agriculture include use of new crop varieties and livestock species that are better suited to drier conditions, irrigation, crop diversification, adoption of mixed crop and livestock farming systems, and changing planting dates (Nhemachena and Hassan, 2007; Kurukulasuriyaand Mendelsohn, 2008;). Adaptation helps farmers achieve their food, income and livelihood security objectives in the face of changing climatic and socioeconomic conditions, including climate variability, extreme weather conditions such as droughts and floods, and volatile short-term changes in local and large-scale markets (Kandlikar et al. 2005).

The agriculture sector has been playing a very significant role in providing food and income to majority of people in rural SSA. It is the mainstay of the region economy by contributing substantially to export earnings and employs majority of total labor forces. The sector is now passing through difficult moment worldwide by being seriously affected by climate variability and change (CV \& C). The impact of CV \& C to agriculture sector is manifesting itself through increasing incidences of floods, droughts and unpredictable rainfall in most parts of the world that affecting crop production and management. These changes contribute to social, political and economic vulnerabilities of people and society (Bardsleyand Wiseman, 2012).

Although CV \& C is global in nature, its potential changes are not globally uniform. The most vulnerable people to global CV \& C are smallholder farmers living in the rural areas that experienced prolonged droughts. The impacts CV \& C on agriculture are the principal factor contributing to poverty to the smallholder farmers by disrupting education, destroying assets, forcing the sale of productive capital and deepening the social differentiation among households. This state of affairs to the smallholder farmers is contributed by prospects of tragic crop failures, reduced agricultural productivity, increased hunger, malnutrition and diseases as a result of climate change (Mary and Majule, 2009; Dejene, 2011). The alternating cycles of droughts and floods do not only destroy the livelihood sources but also severely undermine the resilience of the people living in the affected areas (World Bank, 2008).

Countries in SSA such as DRC are particularly vulnerable to climate change impacts, mostly changes in rainfall, given dependence on agricultural production and limited adaptive capacity (Bryan et al. 2009). The development challenges that many African countries face are already considerable, and climate change will only add to these through losses in farm profits (Kurukulasuriya et al. 2008). The situations are highly serious in SSA. In most African countries including DRC, farming depends almost entirely on quality of the rainy period (Adger, 2006). Climate variability and change influences all the dimensions of food security: food availability, food accessibility, food utilization and food systems stability in DRC. Coping with climatic variability is certainly not new for DRC farmers, but the problem is that existing coping mechanisms may not match with the level of prevailing challenges that are likely to be faced in the future (Bashaasha et al. 2010).

Agriculture is arguably the sector most affected by climate change, but perceptions assessments differ and are thus difficult to compare. As the backbone of DRC's economy, agriculture primarily small-scale mixed crop and livestock production, with very low productivity is very vulnerable to increasing temperatures, droughts and floods, which reduce crop productivity with the moist tropical zone being one of the major foods producing zones. The agricultural sector contributes $18 \%$ of the DRC's GDP and accounts for about $60 \%$ of labor, yet it still fails to establish food security and create enough revenue and sustainable jobs. Nearly half of Congolese people live below the poverty line, and the nation must import more than $70 \%$ of the food it eats (RDC/Ministère de l'agriculture, 2008). With approximately $70 \%$ of its population living in rural areas, the large and mineral-rich land has shown immense potential for sustainable agriculture in the DRC. The development of agriculture and other sectors in the DRC have been hindered by the simple fact that the country has been healing from more than 20 years of war. This has unfortunately created serious infrastructure and systematic issues that have tested the nation's business environment. Thus, poverty reduction in DRC is tied to improvements in the agricultural sector.

The major factors responsible for the low productivity include reliance on traditional farming techniques, soil degradation caused by overgrazing and deforestation, poor complementary services such as extension, credit, marketing, infrastructure as well as climatic factors such as drought and flood (Yirga, 2007). These factors reduce the adaptive 
capacity or increase the vulnerability of farmers to future changes, including climate change, which negatively affect the performance of the already weak agriculture. Consequently, understanding perception and adaptation strategies at a community level is important for achieving sustainable adaptation options in a climate-vulnerable area. The evidence from the Intergovernmental Panel on Climate Change (IPCC, 2007a) is now overwhelmingly convincing that climate change is real, that it will become worse, and that the poorest and most vulnerable people will be affected first and most. One of the sectors most sensitive to global warming is agriculture. For some countries, the decline in yield in rainfed agriculture could be as much as 50 percent. Such trends clearly threaten the achievement of the Sustainable Development Goals (SDGs). Rural households engaged as subsistence and smallholder farmers in developing countries are most vulnerable to the impacts of climate change on agriculture. Understanding the impacts in different locations and the potential responses to cope with them is still at a very early stage, even amongst researchers and governments (UNDP, 2007).

Climate change is an emerging stressor that is experienced over longer time frames via changes in climatic norms and over shorter periods via changes in the frequency and severity of extreme weather events. Climate change is commonly recognized to have major implications for food security and livelihoods (Nhemachena, 2009). In SSA, extreme droughts already impede people's ability to grow food and rear livestock, and pastoralists and agro-pastoralists will need to adapt to changes in water regimes in order to maintain their food security and well-being (Kebede et al. 2011; Songok et al.2011). Adverse effects of climate change continue to be a major threat to rural livelihoods (IPCC, 2007a, 2007b; Nhemachena, 2009;). This poses a challenge of developing innovative technologies to improve rural livelihoods and environmental conservation and ensuring adoption of such technologies. Climate change refers to any change in climate over time, whether due to natural variability or/and as a result of human activity (IPCC, 2007a).

Small-scale farmers, who constitute the bulk of the poor in Africa, face prospects of tragic crop failures, reduced agricultural productivity, increased hunger, malnutrition and diseases as a result of climate change (Zoellick, 2009). Under a 'business as usual scenario', itis projected that crop yield in Africa may fall by $10-20 \%$ by the year 2050 or even up to $50 \%$ due to climate change (Jones, 2003). Countries in SSA, including DRC, are likely to suffer the most because of their geographical location, low incomes, and low institutional capacity, as well as their greater. The present inability to meet the food demand of Congolese and the challenge posed by climate change and variability emphasized the need for the improvement of food crop farmers (Birungi and Hassan, 2010).

The Itombwe Massif region, which lies in tropical-humid ecological zone of the South Kivu Province, is one of the major food production areas in the country. To continue high food production in this region, farmers would have to adapt to climate change. There is, however, little knowledge of how farmers perceive climate change and what adaptation measures theyhave taken. This paper uses the term climate change in a broad context that includes changes in weather variability. Climate change imposes constraints to development especially among smallholder farmers whose livelihoods mostly depend on rain-fed agriculture (IPCC, 2007b). This paper explores farmers' perception of climate change, adaptation measures being employed and investigates the factors and barriers affecting the adaptation process.

\subsection{Research Question and Objective of the Study}

Climate change is a global phenomenon while adaptation is largely site-specific (Mary and Majule, 2009). A common disadvantage for local coping strategies is that they are often not shared widely, but rather handed down through oral history and local expertise (UNFCC, 2003).

Nevertheless, there are some indications of the ways in which climate change will affect small holder farmers (IPPC, 2007a), thus making adaptation a complex and a variable undertaking. A number of issues emerge; these include: (i) increased likelihood of crop failure; (ii) increase in diseases and mortality of livestock, and/or forced sales of livestock at disadvantageous prices; (iii) increased livelihood insecurity, resulting in assets sale, indebtedness, outmigration and dependency on food aid; and (iv) downward spiral in human development indicators, such as health and education. Such impacts will further aggravate the stresses already associated with subsistence production, such as isolated location, small farm size, informal land tenure, low levels of technology and narrow employment options, in addition to unpredictable and uneven exposure to world markets that smallholder farmers particularly risk-prone in the face of climate change. Therefore, the study analyzes farmer's perceptions and adaptation strategies to CV \& $\mathrm{C}$, its determinants and impacts in Itombwe Massif area.

There is an important need of in-depth research and closer scrutiny of how the local climate is changing, what the local communities are thinking about this change, what the small farmers can do in the long term as adaptations, and possible interventions/future investments needed to deliver sustainable results. So, to understand the nexus of climate change and sustainable development, what needed is an in-depth field survey to find out the local community's ideas and perceptions and how they are responding to climate irregularities. It is hypothesized that in response to the climate change the small farmers, in the way of the process of adaptation to all changes and survival strategy, may have modified and/or replaced many practices which have become unsustainable and adopt new ones can be demonstrated in the present study in the Itombwe Massif area.

This study explored smallholder farmers' knowledge on perceptions, vulnerability, adaptations and coping strategies, coupled with scientific analysis of the prevailing climatic regimes in the areas of study and established enhanced adaptations of the agricultural systems. The information accrued from the study is expected to be used by stakeholders including scientific communities and policy makers to address issues related to CV\&C in similar agro-climatic conditions. Overall, the study aims to assess the causes, indicators and determinants of climate change based on smallholder farmers' perception. factors affecting the choice of adaptation methods in crop production systems by taking the case of farmers in the local community to bridge this gap of knowledge in order to guide policymakers on ways to promote adaptation under changing climate. 
Specifically, the study is designed to address the following: (i) assess the existing knowledge that smallholder farmers have on, and the different levels of climate change risks perceived by farmers in Itombwe massif; (ii) explore the adaptation strategies farmers have already adopted to cope with the consequences of climate change and adapt to the perceived trends of rainfall and crop productivity; (iii) establish the trend of climate variability from temperature and rainfall records from 2010 to 2019 and identify the perceived barriers to climate change adaptation strategies; (iv) analyze the socio-economic determinants of farmers' adaptations to climate change, and (v) recommend plausible policy interventions that match farmers, perceptions, experiences, adaptation strategies and coping mechanisms while considering further research and development activities in the Itombwe massif.

\subsection{Research Question}

What is the trend of climate variability and change from temperature and rainfall records from 2010 to 2019 in Itombwe massif region?

\subsection{Research Hypotheses}

- $\mathrm{H}_{0}$ : Climate variability and change in Itombwe massif region has no relationship with crop productivity in the area;

- $\mathrm{H}_{1}$ : There is variation in the perception of the impacts of climate variability and change on crop productivity among the farmers in Itombwe massif region;

- $\mathrm{H}_{2}$ : adaptation measures in Itombwe massif region do not necessarily translate into changes because there are context-specific social, economic, cultural, psychological and environmental barriers to adaptation.

\section{Materials and Methods}

\subsection{Study Areas and Survey Design}

The Itombwe Mountains lie northwest of Lake Tanganyika in the DRC, within the extensive mountain range running along the Western Rift, or Albertine Rift, from the Ruwenzori Mountains in the north to the Marungu Highlands in the south (Figure 1). They are thought to be an important site for biodiversity conservation in SSA and have been identified among DRC forests as a focus for the conservation of biodiversity and ecological processes (Doumenge, 1990). This area is well known among conservationists for its rich and unique fauna (Doumengeand Schilter, 1997; Mubalama, 2018; Mubalama et al. 2018) including, mammals, such as primates (the most striking being the Eastern Gorilla), birds (Prigogine, 1984, 1985), and amphibians (Laurent, 1964). These mountains shelter the most diverse montane bird community in continental Africa, comprising 90 percent of endemic species of the Western Rift. Some birds and amphibians are strictly endemic to the area (Laurent, 1964; Prigogine, 1985; Collar and Stuart, 1988; Mubalama et al. 2018). The region is inhabited by various human groups. In northern Itombwe, population densities are higher than 100 inhabitants $/ \mathrm{km}^{2}$, mainly related Bafuliro, Banyindu, and Bashi people, the latter being located chiefly in the Bukavu area. On the western slope and the Itombwe high plateaus, human population densities vary from 10 to 20 inhabitants $/ \mathrm{km}^{2}$. The Balega people live in western Itombwe, as well as farther west, while the related Babembe inhabit the south-center of the region. During this century, the Babembe have been joined by the Banyamulenge refugees fromRwanda and tensions between these very different rural groups are prevalent. Other groups, such as Bavira, live along the Ruzizi River and the shoreline Lake Tanganyika where population densities are high (50-140 inhabitants/ km² (Doumenge, 1998).

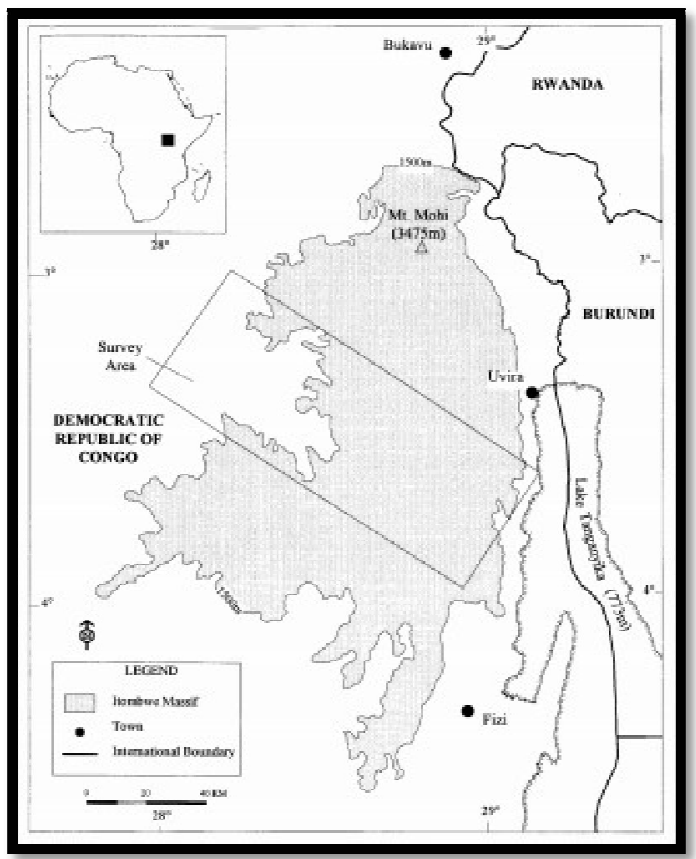

Figure 1: Itombwe Massif Mountains,Omari et al. (1999) 


\subsection{Hypotheses of Explanatory Variables}

The dependent variables in this study are perception and adaptation, while the explanatory variables are based on available data that include: household characteristics (the level of education, age, and gender of the head of the household), years of faming experience, farm size, access to markets, access to agricultural extension services, access to credit/loan, land tenure, and soil fertility. The hypotheses explaining how explanatory variables influence the perception and adaptation to climate change is presented below.

Education: Farming experience and perceptions are important factors influencing adoption decisions. Several studies have shown positive relationship between the education level of the household head and the adoption of improved technologies (Deressa et al. 2009) as well as adaptation to climate change (Maddison, 2006). Hence, farmers with higher levels of education are more likely to adapt to climate change. Educated and experienced farmers are expected to have more knowledge and information about climate change and agronomic practices that they can use in response (Maddison, 2006). We expect that improved knowledge and farming experience will positively influence farmers' decisions to take up adaptation measures.

Various studies have shown that gender is an important variable affecting adoption decision at the farm level. Female farmers have been found to be more likely to adopt natural resource management and conservation practices (Dolisca et al. 2006; Bayard et al. 2007). However, some studies found that household gender was not a significant factor influencing a farmer's decisions to adopt conservation measures (Bekele and Drake, 2003). We hypothesize that femaleand male-headed households differ significantly in their ability to adapt to climate change because of major differences between them in terms of access to assets, education and other critical services such as credit, technology and input supply. Gender of the household head is hypothesized to influence adaptation decision to changes. In SSA, female-headed households are often poorer than male headed households, and many studies have been done on the association between gender and wealth (Fosu-Mensah et al. 2010).

Farmer socioeconomic attributes: The empirical adoption literature shows that household size has mixed impacts on farmers' adoption of agricultural technologies. Larger family size is expected to enable farmers to take up labor intensive adaptation measures (Dolisca et al. 2006; Anley et al. 2007). However, the opportunity cost of labor might be low in most smallholder farming systems as off-farm opportunities are rare. We therefore expected that farm households with more labor are better able to take up adaptations in response to changes in climate.

Access to credit: Several studies have shown that access to credit is an important determinant enhancing the adoption of various technologies (Kandlikaret al. 2005). With more financial and other resources at their disposal, farmers are able to make use of all Access to credit/loan facility is very important when it comes to adaptation of new technology and climate change as ease of access to cash allows farmers to purchase inputs like improved seeds and fertilizers. Research on adaptation to climate change indicates that there is a positive correlation between adaptation and the availability of credit (Deressa et al. 2009; Gbetibouo, 2009).

Market access: is another important factor affecting adoption of agricultural technologies (Feder et al. 1985). Input markets allow farmers to acquire the inputs they need such as different seed varieties, fertilizers and mixed crops technologies.

\subsection{Data Collection and Analysis}

\subsubsection{Data Source and Methods of Data Collection}

A cross sectional household survey was carried out using a standard structured questionnaire applying both qualitative and quantitative methods of data collection and analysis. The questionnaire assessed demographic characteristics, perceptions of changes in rainfall, temperature and extreme weather events in the last 10 years, how changes in climate have affected crop production in the last 10 years and the changes made by farmers on their farms within the last 10 years because of changes in climate. The questionnaire was pre-tested on five households in Itombwe massif considering both the forestdominated landand savannah area and accordingly revised to produce the final questionnaire that was used in the study. Information to be collected was characterized in three categories in accordance to Newing (2011) being: basic characteristic of respondents; information on knowledge (memories and experiences regarding climate change) and information on behavior (adoption of best farming practice).

Based on the above criteria a multi-stage, purposive sampling method was used to select the villages within the groupement (chiefdom administrative unit). Selection of the villages to be surveyed was further guided by knowledge of local leaders and ease of accessibility. Respondents were distributed in 28 Villages. Enumerators were first trained on the study tools and questionnaires prior to the data collection exercise. People who were about 30 years of age or more and had lived in that village for the past 10 years or more were only considered in the study to ensure that respondents make meaningful comparisons between the past and the present. Interviews of the selected respondents were conducted in their homes. A total of 400 farmer households were interviewed individually between October 2015 and March 2016 (Mubalama et al. 2020).

The relevant data to this study were collected from both primary and secondary sources. The primary source is a cross-sectional survey data collected from a total of 400 households randomly sampled farmers were interviewed using a structured questionnaire. The primary data majorly include demographic, socioeconomic, institutional, and biophysical attributes. The data also include information on farmers' perception of the patterns of temperature and rainfall over the past 10 years. Survey questionnaires, focus group discussion, and field observation were the data collection methods employed. Household-level data were collected through an open and close-ended survey questionnaire (Bryman, 2008). Five focus group discussions, each comprising ten persons, were also carried out to substantiate the responses acquired 
using the questionnaire. The primary data from the field survey were supplemented with data obtained from secondary sources. Females accounted for $43.2 \%$ of respondents and males $56.8 \%$. The average age for respondents was 45.8 years with $65.5 \%$ being above 30 years of age. Majority (68.7\%) had not more than 7 years of primary education.

For information on personal attributes, respondents were asked to state their age or when they were born and highest level of formal education attained. On information on respondents' knowledge, questions sought causes of climate change, perceived changes on onset and offset of seasons, duration of seasons, coldness, hotness, frequency of droughts and floods. Questions were framed in a way that allowed respondents to compare conditions in the recent past (less than 5 years) and long time ago (time from their teenagerhood). The period of teenagerhood was used because farmers could more easily relate to such specification of time compared to using numbers such as 30 years ago. This became apparent during the pre-testing of the questionnaire. Focus group discussions, key informant interviews and review of secondary data were also conducted (Newing, 2011) to double check the household survey and the general perception of farmers on climate change.

Respondents were asked if they had experienced any change or not in the onset and offset of seasons since their teenagerhood. If respondents had experienced any change, they were asked to state whether the onset of a season came early or delayed in the recent past as compared to a long time ago. Bryman (2008) emphasizes the importance of ensuring trustworthiness, that the responses and findings are believable, in social research.

Therefore, respondents were asked to state months for the onset and offset of respective seasons in the recent past and a long time ago to allow cross-checking of responses. This was also useful in calculating the durations of seasons in the recent past and long time ago in order to determine any perceived changes in duration. For perceptions of changes in coldness, hotness, droughts and floods, farmers were asked to state if conditions had increased, decreased or remained the same since their teenagerhood as compared to the recent past. Farmers were also asked to list causes of climate change, positive and negative effects of climate change that they have experienced and responses they have undertaken. For the information on behavior (adoption of sustainable agriculture in this case), respondents were asked to state if they had any area under sustainable agriculture.

Area under minimum tillage was used as a proxy indicator for adoption of sustainable agriculture. Descriptive statistics was used to analyze quantitative data and results were presented either as percentages or counts. Percentage of farmers who cited sustainable agriculture as a response to climate change was used to indicate the extent to which sustainable agriculture was perceived as an adaptation strategy. Pearson Chi-Square ( $\chi 2)$ test was used to determine at $5 \%$ significance level any association between smallholder farmers' perceptions of climate change and their adoption of sustainable agriculture.

This also provided a check for consistency in farmers' responses and perceptions in accordance to the requirement of ensuring credibility of results (Newing, 2011). Content analysis was used in the analysis of qualitative data (Bryman, 2008). Lists of causes of climate change, effects and responses undertaken were summarized according to emerging themes and presented as counts. Qualitative analysis of information from focus group discussions and key informant interviews is a continuous process starting during data collection with identification of major themes and ending with an in-depth description of the results. In accordance to Newing (2011) data from focus groups and key informants was summarized according to key themes and illustrated by direct quotes, recounting particularly relevant experiences and views of smallholder farmers, essential for authenticity of findings.

To understand the perception of the local communities about climate change, a group of statements were prepared, Likert Scale (Likert, 1974). was used to understand community perception on climate change, its impacts and coping strategies. The levels of community perception were rated form 'strongly agree' (5) to 'strongly disagree' (1) on the scale from responses to the statements summarized and presented to indicate important characteristics of climate variability, its impacts on their livelihoods at local level and local coping strategies from the community's insight.

For examining the community's climate related understanding, experiences and its relation to their livelihoods, an approach similar to that used by 'USAID-Participatory Assessment and Learning Tool «for assessing how community members understand climate have been used (USAID, 2007). A focus group of elderly men (15) and women (10) who have been living for long (over 50 years) in the area were selected from the community to discuss about climate and farming (crops, animals and trees). The discussion was facilitated in local language (Lega, Bembe and Swahili), as these community members lived for long periods in the area had good understanding of conditions and changes in their surrounding and also about the 'normal climate conditions'. Discussion was started by posing questions such as what are the 'good' seasons and what were the 'bad' seasons, how did they understand and describe climate and climate change at the local levels. The participants described 'good season' as that give enough rain with regular distribution that can support crops, trees and animals in sufficient amount, there would be no fear of starvation and insecurity to the family; whereas they described 'bad' season associated with low and irregular rains, heat, hails and storms bringing crop damage and the fear to face food shortage, starvation and insecurity to the family. The participants were solicited to identify and list the bad and good points of the earlier as well as during recent years in a chart and filter tip pen, the main memorable indicators of climate situation in the area from past were identified by the participants as rain fall, heat, hail and coolness. They also indicated what steps they already had taken or would take under the 'problem' situations.

\section{Method of Data Analysis}

Data was entered using MS Excel and exported to STATA for basic descriptive statistical analyses. The data analysis was done by descriptive statistics and econometric model (Heckman's sample selection model) using STATA 12 and SPSS 25 (SPSS, 2017). The descriptive statistics were employed to describe farmers' perception of climate shocks, responses implemented to address the shocks, and the constraints faced in implementing the responses. The Heckman's 
(1976) sample selection model was employed to analyze the two-step processes of location specific adaptation to climate change.

\subsection{Dependent and Independent Variables}

Dependent variables are:

- Whether A Farmer Has or Has Not Perceived Climate Change (Table 7);

- Whether A Farmer Has or Has Not Developed Coping Strategies to Climate Change (Table 7).

Independent variables (Table 8) include age and education of the head of the household, household size, land holding, farm labor, ability to pay/hire labor, ownership of livestock, non-farm income source, access to credit, social capital, farming experience,intercropping receiving weather forecast, intercropping on the farm, and the use of local signs to predict seasons.

\subsection{Models Specification}

Based on Heckman (1976), when a farmer's decision process about the adoption of a new technology requires more than one step, models with two-step regressions, such as Heckman's sample selection, are appropriate to correct for selection bias generated during the decision-making processes. The Heckman's sample selection model is based on the farmer's utility or profit maximizing behavior, and the assumption is that a farmer uses a new technology only when the perceived utility or profit from using the new technology is significantly greater than the traditional or the old method.

Similar to technology adoption, adaptation to climate change is a two-step process that involves perceiving that climate is changing and then responding to the change through adaptation measures (Deresa et al. 2011; AsratandSimane, 2017). Therefore, the Heckman probit selection model is employed in this study to investigate the determinants of perception and adaptation to climate change. The first stage of the model (the selection model) considers whether a farmer perceived a change in the climate, and the second stage of the model (outcome model) explores whether the farmer adapted to climate change conditional on the first stage.

In the two-stage process, the second stage of adaptation is a sub-sample of the first. Thus, it islikely that the second stage sub-sample (those who responded to change) is non-random and necessarily different from the first (which included those who did not perceive climate change), and this creates a sample selection bias (Deresa et al. 2011; Asrat andSimane, 2017). Therefore, the Heckman two-step maximum likelihood procedure was used to correct for this selection bias. The underlying relationship in the Heckman's sample selection model consists of a latent equation given by:

$\mathrm{yj}=\mathrm{X}_{\mathrm{j}} Y \mathrm{j}=X j \beta+u j$

$\mathrm{y}_{1}$ prohit $=(Y>0)$

$\mathrm{y}_{1}$ select $=z j \delta+u 2 j>0$

The dependent variable is observed only if $j$ is observed in the selection equation

$u 1 \sim N(0,1)$

$u 2 \sim N(0,1)$

$\operatorname{Corr}(\mathrm{u} 1, \mathrm{u} 2)=\rho$

where $\mathrm{y}_{1}$ selectis whether a farmer has perceived climate change or not, $\mathrm{z}$ is an $\mathrm{m}$ vector of regressors, which include different factors hypothesized to affect perception; $\delta$ is the parameter estimate, $\mathrm{u} 2 \mathrm{j}$ is an error term and $\mathrm{u} 1$ and $\mathrm{u} 2$ are error terms, which are normally distributed with mean zero and variance one. Thus, Eq. 3 is the first stage of Heckman's two-step model which represents the farmers' perception of changes in climate.

Equation 1 is the outcome model which represents whether the farmer adapted to climate change, and is conditional upon the perception model.

When the error terms from the selection and the outcome equations are correlated $(\rho \neq 0)$, the standard probit techniques yield biased results (Deresa et al.2011; AsratandSimane, 2017). Thus, the Heckman probit (heckprob) provides consistent and asymptotically efficient estimates for all parameters in such model.

The dependent variable for the selection equation is whether a farmer has or has not perceived climate change. The explanatory variables include sociodemographic, environmental, and institutional factors selected based on hypothesized relationships described in literature on factors affecting the awareness of farmers to climate change or their risk perceptions (Deresa et al. 2011; AsratandSimane, 2017) and field observations made in the study area. In the case of the outcome model, the dependent variable is whether a farmer has adapted or not to climate change. The explanatory variables are chosen based on the climate change adaptation literature (Hassan andNhemachena, 2008; Deresa et al. 2011; AsratandSimane, 2017) and field observations made in the study locations. The hypothesized explanatory variables for the Heckman's two-step model used in this study are described in the section that presents the empirical model results.

For statistical analysis, the logit model was employed due to the nature of the decision variable; whether farmers perceived climate change and have adapted or otherwise. For such a dichotomous outcome, the logit model is the most appropriate analysis tool. The logistic model considers the relationship between a binary dependent variable and a set of 
independent variables, whether binary or continuous. The logistic model for ' $\mathrm{k}$ ' independent variables $(\mathrm{Xi}, \mathrm{X} 2, \mathrm{X} 3, \ldots, \mathrm{Xk})$ is given by

$$
\operatorname{Logit} \mathrm{P}(\mathrm{x})=\mathrm{a}+\sum_{i=1}^{k} B 1 x 1
$$

Exp (bi) indicates the odds ratio for a person having characteristics i versus not having i,

while bi is the regression coefficient, and a is a constant.

\section{Results and Discussion}

\subsection{Farmers' Perceptions about Changes in Climatic Variables}

Nearly all the households (81.7\%) interviewed had observed a change in the climate in the last 10 years. The percentage of households reporting that rain came late (49.2\%) were nearly equal to those reporting rain to be coming early (47.1\%). Forty percent reported that rain increased in amount and intensity, 17.4\% declared that rain decreased, while $38 \%$ perceive rain to be extreme (Figure 2). The highest proportion of farmers (38.8 \% households) perceived an increase in temperature in the last 10 years, while $13.5 \%$ of the households did not observe any change in temperature (Figure 3).

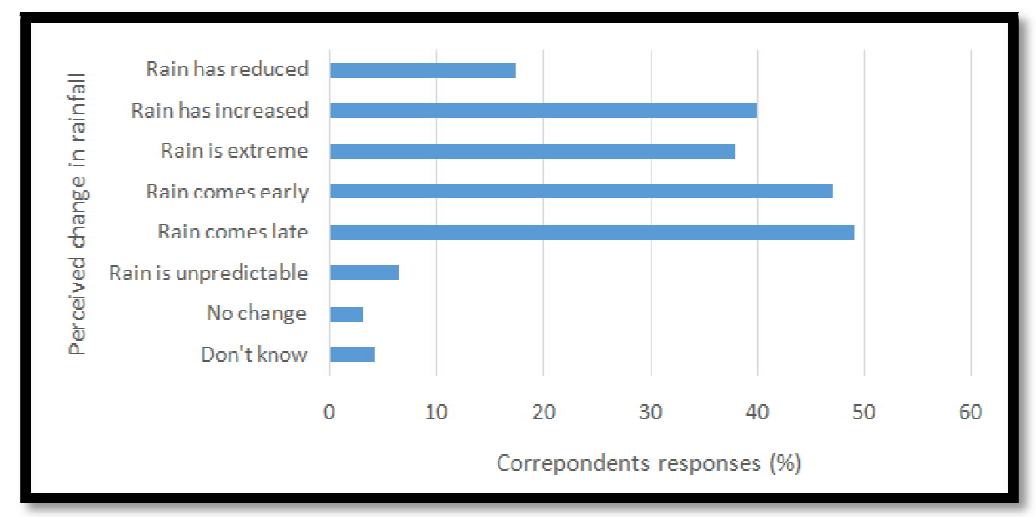

Figure 2: Farmer Perception of Changes in Rainfall in the Last 10 Years (\% Households)

Extreme climatic events like floods, drought/prolonged dry seasons, and storms were reported to have increased in the last 10 years (Figure 4). Perception to climate change was indeed influenced by the agro-ecological zone (forest versus savannah habitats).

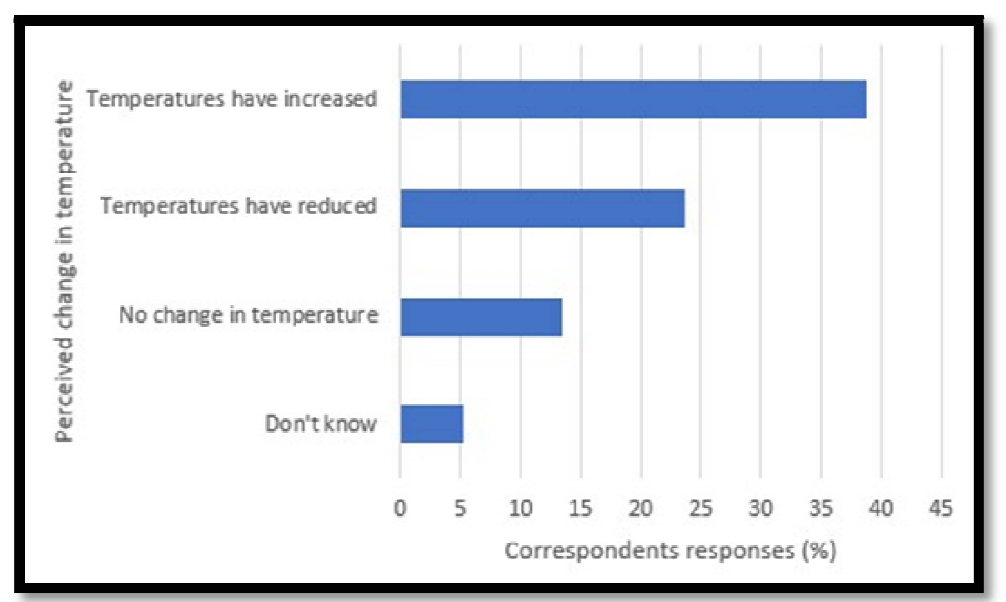

Figure 3: Farmer Perception of Changes in Temperature in the Last 10 Years (\% Households)

Among the $81.7 \%$ that had observed a change in the climate in the last 10 years, either perceived or no perceived, the descriptive analysis indicated that about 52\% of the respondents from the forest dominated land and $62 \%$ from the savannah had perceived a change in climate. (Table 1). It's noteworthy to mention that only 16 people (4\%) among384 informants confirmed that they don't know about any change observed in the last 10 years (Table 1).

Most smallholder farmers perceived supernatural forces as cause of climate change (Table 2). Farmers often referred to the Bible arguing that disobedience of humankind to God's principles and/or lack of respect to ancestral spirits and other customs caused climate change. Most farmers felt that the rainy season started later (49.2\%) and stopped earlier in the recent past as compared to a long time ago, while other $47.1 \%$ confirmed that the rainy season started early (Figure 2). A 61 years old farmer explained that: '...there were clear cut differences in the seasons when we were young but 
nowadays there is a lot of confusion in the weather forecast... Seasons are not clear cut nowadays...' another farmer stated "Rain nowadays just comes in a haphazard manner, whenever it wants and goes at any time. "Sometimes it rains continuously such that we cannot go out to the gardens nor do any field work. Other times instead of the rains reducing and stopping, it continues and sometimes falls heavily destroying our crops that were ready for harvesting. "It is difficult to understand the seasonal weather nowadays... 'Weather keeps changing every 5 or 10 years...' Only God knows as stated by $71.5 \%$ of informants in table 2 .

One of the most prominent responses from interviewees across the Itombwe massif, as well as from questionnaire respondents across the study area is the marked observation that there have been more instances of extreme weather, including weather variability. Such observations by above mentioned informants coincide with recorded changes in extreme weather and the apparent increase in frequency of flood occurrence. Losses incurred by farmers from extreme weather have increased and observed increases in the scale of impacts of such events is apparent.

\begin{tabular}{|c|c|c|c|c|c|c|c|c|}
\hline \multirow{2}{*}{ Perception } & \multicolumn{2}{|c|}{ Forest land } & \multicolumn{2}{|c|}{ Savannah land } & \multicolumn{2}{|c|}{ Total } & \multirow{2}{*}{$\boldsymbol{x}^{2}$ value } & \multirow{2}{*}{ P value } \\
\cline { 2 - 8 } & $\mathrm{N}$ & $\%$ & $\mathrm{~N}$ & $\%$ & $\mathrm{~N}$ & $\%$ & & \\
\hline Not perceived & 92 & 48 & 73 & 38 & 165 & 43 & $3.687^{* * *}$ & 0.003 \\
\hline Perceived & 100 & 52 & 119 & 62 & 219 & 57 & & \\
\hline Total & 192 & 100 & 192 & 100 & 384 & 100 & & \\
\hline
\end{tabular}

This difference in perception of climate change between the two locations is statistically significant $(\chi 2=3.687$ with $\mathrm{P}<0.003$ (Table 1).

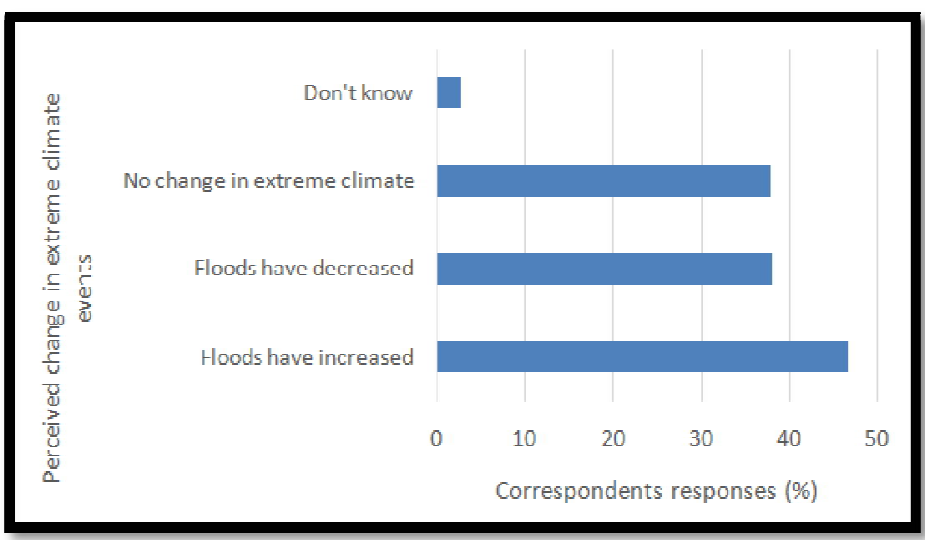

Figure 4: Change in Occurrence of Extreme Events in the Last 10 Years (\% Households)

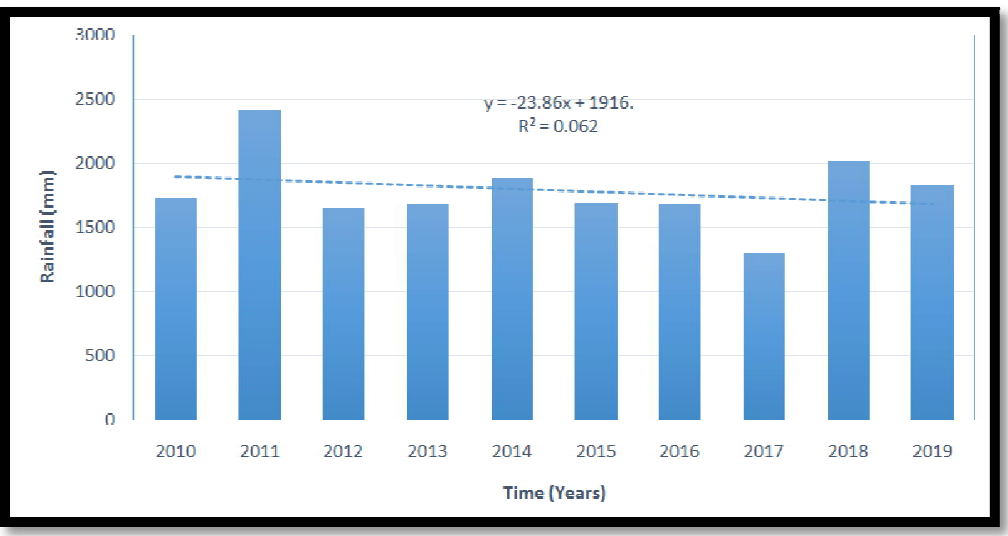

Figure 5: Historical Mean Annual Rainfall (Mm) In Itombwe Massif

(Source:AgMERRA Dataset, (2019). MERRA-NASA, corrected by AgMIP. Https://power. larc.nasa.gov/.data-access-viewer/ 


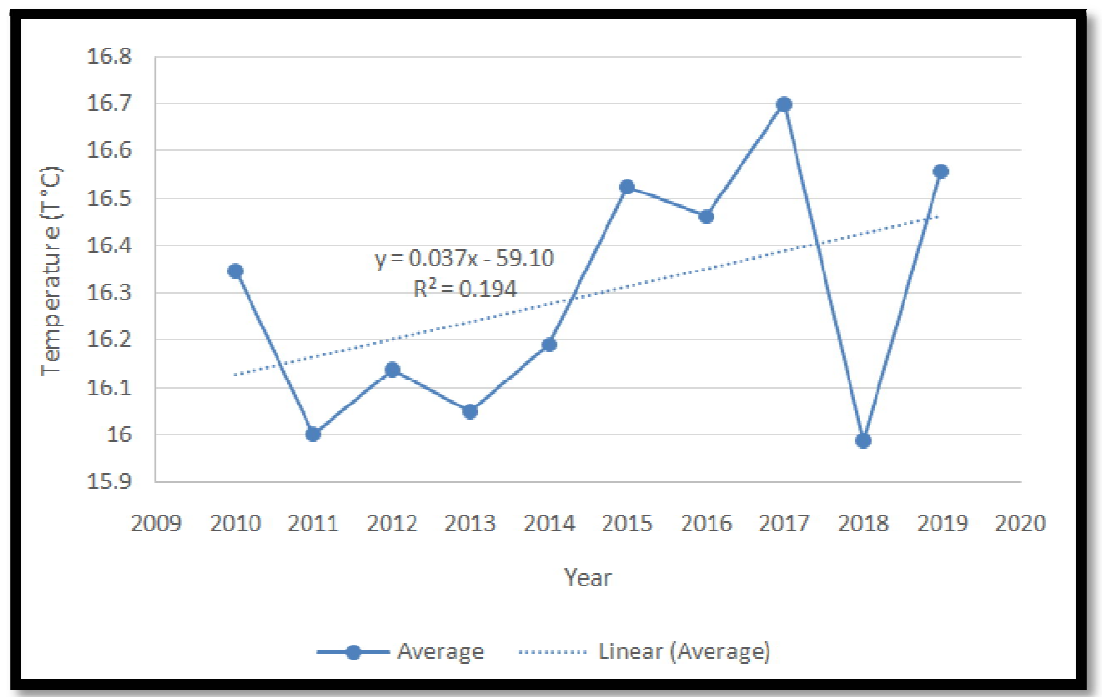

Figure 6: Average Temperature Changes in Itombwe Massif

\subsection{Trend of Climate Variability and Change from Temperature and Rainfall Records between 2010 and 2019 in Itombwe Massif}

The trend analysis was based on climate data (rainfall and temperature) obtained from AgMERRA (2019) Meteorological dataset. The data obtained included temperature $\left({ }^{\circ} \mathrm{C}\right)$ and rainfall $(\mathrm{mm})$ from 2010 to 2019. Temperature and rainfall are used for respective data collection for years and their long-term values to capture climate variability and change respectively and to estimate the short and long-term effects of climate change on food productivity. According to the meteorological information obtained, the ten-year data (2010-2019) was divided into five years' interval for quick analysis, interpretation and presentation on the variability of temperatures and rainfall patterns as they influence food security in Itombwe massif. The study also indicates that average temperature changes in the study area has been changing overtime from 2010 to 2019. Average maximum temperature in 2019 was 16.56 degree Celsius compared to 2010 record of 16.35 degree Celsius. This shows that temperature is changing and the changes are not consistent. It can be observed that temperature started rising from 16.35 degree Celsius in 2010 and reached its peak at 16.70 degree Celsius in 2017 (highest rising temperature record during the decade) and then started falling at 15.99 degree Celsius in 2018 before rising at 16.56 degree Celsius in 2019. The average record of temperature data from the Itombwe massif between 2010 and 2019 shows an increasing trend (Figure 6). Also, Figure 5 revealed the recorded data on rainfall from 2010 to 2019 showed a decreasing trend for the study area.

In 2010 to 2019, the highest rainfall parameters recorded were $2415.42 \mathrm{~mm}$ during the year of 2011 compared to $1292.06 \mathrm{~mm}$ lowest recorded in 2017 (highest rising temperature record during the decade). This means that between the years 2010 and 2017, there was a high variability in rainfall patterns from $2415.42 \mathrm{~mm}$ to $1292.06 \mathrm{~mm}$. This variability had a negative impact in crop production that was responsible for low crop production due to insufficient rainfall in 2017 with $1292.06 \mathrm{~mm}$.Accordingly, rainfall variability during the period of 2016 to 2019 indicates a slightly relative variability and was therefore responsible for a steady food crops production. This variability in the season suggests a likely shift in the rainfall pattern that has a serious consequence on rain-fed agriculture (Fosu-Mensah, 2011), hence worsening the already existing problem of food insecurity and poverty.

Farmers should be able to adapt in order to reduce the negative impact of climate change. Adaptation to climate change is a two-step process which requires that farmers perceive climate change in the first step and respond to changes in the second step through adaptation. Different socio-economic and environmental factors affect the abilities to perceive and adapt to climate change. Unlike the prior expectations, farmers living in the savannah dominated areas (Kipupu, Tulambo, Mikenge, Magunda, Lubumba, Epombo, Rushasha, Makutano, Malanda I, Malanda II, Lwemba, Abangya, Lubunga and Tabunde) perceived more change in climate than farmers in the forest habitat (Kitongo, Malenge, Ibachilo, Ngomiano, Kabelukwa, Kitibingi, Lueno, Tusani, Kitopo, Ebonga, Milanga, Kapanga, YatambwaandTshona). This could either be associated with the drought event (year 2017), with or could be linked to various environmental changes that cause reduced water availability (Meze-Hausken, 2004). It might also be linked to various problems such as soil erosion, which reduces yield, or population pressure, which increases demand for food. According to Bucekuderhwa and Mapatano (2013), food insecurity in South Kivu is a reflection of poverty, which is a mass phenomenon that tends to recur and be passed on from one generation to the next (Lukuli, 2006). Demographic pressure, fluctuations in food prices and sociopolitical insecurity are sometimes cites as the factors causing food insecurity in the countryside.

\subsection{Smallholder Farmers' Interpretations of Future Climate Change}

A strong association between of perception of experiences of the weather in the past and present has been found. However, there is little link between present observations and experiences and future risk perception. Instead, an apparent gap between farmers' perceptions of present and future climate is identified from this analysis. Perspectives of future climate change are continually changing, and so a complex web of risk perceptions, experiences, knowledge and communication exists. 


\begin{tabular}{|llll|}
\hline \% Farmers that confirm & Forest habitat & Savannah & Total (\%) \\
& & & \\
\hline Crop productivity for the last decades & 5.0 & & \\
Increase & 37 & 9.6 & 14.6 \\
Decrease & 1.0 & 1.6 & 2.8 \\
No change & & & \\
Crop productivity in the future & & & \\
Increase & 6.4 & 15.2 & 21.6 \\
Decrease & 7.0 & 49 & 56 \\
No change & 2.7 & 12.4 & 15.1 \\
Only God knows & 28 & 43.5 & 71.5 \\
\hline
\end{tabular}

Table 2: Assessment of Farmers' Perception the Impacts of Climate Variability and Change on Crop Productivity in Itombwe Massif Source: Field Survey Data, 2016

\begin{tabular}{|llll|}
\hline \% Farmers that confirm & Forest habitat & Savannah & Average \\
& & & \\
\hline Trend of rainfall for the last decades & & & \\
Decreasing & 15 & 13.4 & 8.7 \\
increasing & 4.0 & 2.6 & 1.6 \\
No change & 0.6 & 39 & 24.6 \\
Comes late & 10.2 & 38.9 & 23.55 \\
Comes early & 8.2 & & \\
Trend of rainfall in the future & & 28 & 21.5 \\
Decreasing & 15 & 10 & 15 \\
Increasing & 20 & 28 & 17.5 \\
No change & 07 & 58 & 63 \\
Only God knows & 68 & & \\
\hline
\end{tabular}

Table 3:Farmers' Opinion on Trends in Rainfall in Itombwe Massif Source: Field Survey Data, 2016

\begin{tabular}{|lccc|}
\hline $\begin{array}{l}\text { Short-term coping } \\
\text { strategies }\end{array}$ & Forest habitat & Sovannah & Average \\
& & & \\
\hline Handicraft making for sale & 16.8 & 9.1 & 12,95 \\
Off-farn job/Retail business & 32 & 36 & 34 \\
Accessing relief prograrımes & 49 & 60 & 54.5 \\
Use improved seeds & 25 & 63 & 64.5 \\
Casual labor/small-scale mining & 65 & 68 & 60.5 \\
Accessing microcredit & 53 & 55 & 37.5 \\
Using social security system & 20 & 38.9 & 33.95 \\
Different crop varictics & 29 & 50.7 & 34.85 \\
Reduce number of livestock & 19 & 44.7 & 32.35 \\
Charcoal production & 20 & 38.1 & 23.05 \\
Adjusting calendar planting & 8.0 & 5.1 & 3.4 \\
Change from livestock to crops & 1.7 & 4.4 & 3.0 \\
Lease land & 1.6 & 27.3 & 23.4 \\
No adaptation & 19.5 & & \\
\hline
\end{tabular}

Table 4: Farmers' Coping Strategies to Unexpected Crop Failure in Itombwe Massif Source: Field Survey Data, 2016

In order to understand the perception of farmers on crop productivity, they were asked to give their opinion on the trend of crop yield per hectare on their own plots for the last 10 years. Table 2 shows the extent to which CV \& C has affected the food availability. Results of farmers' perception of the trend in crop productivity over the last decades indicate that a significant majority of the farmers (82.8\%) report that crop productivity has declined over the last decades (Table 2).

However, results were quite variable among the two study areas. In the savannah areas, including Kipupu, Lubumba, Tulambo, Rushasha and Makutano which are located in the open habitat dominated part of the study area, perceived decline in crop productivity is the largest (45.8\%) while in the forest land perceived decline in crop productivity is the smallest (37\%). In general, the percentage of farmers perceiving that crop productivity has remained the same over the last decades is low (only 2.6\%). When farmers were requested to predict crop productivity in the future, a majority was not able or uncertain to give a clear opinion and mentioned that only God knows (39\%) about the future (Table 2). It is remarkable that in the savannah dominated areas, farmers were less pessimistic about this future trend than in the other domains. Fifty-two percent of the farmers surveyed in Magunda, Kipupu and Lubumba believe that there will be a decline in crop productivity in the future. A possible explanation is that farmers in these villages were so pessimistic because of being affected by frequent yield reductions in the previous years. Given that decline in rainfall was frequently mentioned as the main cause of declining crop productivity during focus groups discussion, farmers were also requested to give their opinion on rainfall trends. Indeed, a majority (11\%) of farmers in savannah over the total of $17.4 \%$ reported 
that the amount of annual rainfall has decreased over the last decades (Figure 2). Such a perception is quite common for farmers and has been observed also in studies in the Nile Basin of Ethiopia (Bryan et al. 2009; Deressa et al. 2009) and in West Africa (Lodoun et al. 2013). Our findings indicate that farmers directly relate yield reductions and food shortage to a decrease in rainfall.

\begin{tabular}{|c|c|c|c|c|c|c|}
\hline \multicolumn{7}{|c|}{ Crosstab } \\
\hline & & & \multicolumn{3}{|c|}{$\begin{array}{l}\text { Extent of Climate Variability and } \\
\text { Change on the Food Availability }\end{array}$} & \multirow[t]{2}{*}{ Total } \\
\hline & & & Increased & Decreased & No change & \\
\hline \multirow{4}{*}{$\begin{array}{c}\text { Climate } \\
\text { variability } \\
\text { and change }\end{array}$} & \multirow[t]{2}{*}{ Yes } & Count & 53 & 319 & 8 & 380 \\
\hline & & & $13.9 \%$ & $83.9 \%$ & $2.1 \%$ & $100 \%$ \\
\hline & \multirow[t]{2}{*}{ No } & Count & 6 & 12 & 2 & 20 \\
\hline & & & $30 \%$ & $60 \%$ & $10 \%$ & $100 \%$ \\
\hline \multirow{2}{*}{\multicolumn{2}{|c|}{ Total }} & Count & 59 & 331 & 10 & 400 \\
\hline & & & $14.6 \%$ & $82.8 \%$ & $2.6 \%$ & $100 \%$ \\
\hline
\end{tabular}

Table 5: Extent to Which Climate Variability and Change Has Affected Crop Productivity Source: Field Survey Data, 2016

\begin{tabular}{|c|c|c|c|c|}
\hline \multicolumn{5}{|c|}{ Chi-Square Test } \\
\hline $\begin{array}{c}\text { Pearson Chi- } \\
\text { Square }\end{array}$ & 2.24385 & Df & Sig. Level & \\
\hline
\end{tabular}

Table 6: Chi-Square Result of Climate Variability and Change Impacts on Food Availability

As indicated in the Chi-Square, the results show that the Climate variability and change in Itombwe massif has relationship with food availability in the area $(\mathrm{P}<0.05)$ This implies that climate variability and change impacts had influence on food availability in the study area during 2010 to 2019.

Table 5 shows the extent to which CV \& C has affected the food availability. $13.9 \%$ of respondents believed that there is climate variability and change in their community and it has declined food availability, 83.9\% also believed that there is climate variability and change in their community and believed that it has decreased the extent of declining the food availability while only $2.1 \%$ respondents thought that there is climate variability and change in their community and agreed that it has not change the extent of declining the food availability. However, about $30 \%$ of respondents believed that there is no climate variability and change in their community but claimed that climate variability and change has increased the extent of declining the food availability, while $60 \%$ of respondents believed that there is no climate variability and change in their community but agreed that climate variability and change has decreased the extent of declining the food availability.

Climate change, particularly in fluctuations in rainfall, is a major constraint to agricultural development. Farmers in the study area face a double problem of low and fluctuating rainfall. Years an abundance of rain do not necessarily translate into adequate humidity conditions for crops due to poor distribution in the rainy months (Figure 5). Empirical studies show that there is a correlation between annual rainfall and the number of rainy days (FA0, 2007; Bucekuderhwa and Mapatano, 2013).

For the past few decades, agriculture in many parts of Itombwe massif has faced a decrease in production per hectare (Jayne et al. 2010, Bucekuderhwa and Ngendakuriyo, 2011). As a result, people suffering from lack of food due to frequent climate incurred crop failures has increased and the majority in rural areas live without meeting their most basic nutritional needs, Prskawetz et al. (2003) highlight the relationship between food insecurity, low agricultural productivity and inequality in food distribution. Recent trend in climate variability and change that has affected crop productivity is noteworthy (Table 5). Results of the Heckman prohibit selection model (two-step) predict to moderate reductions of potential crop yields (Stern, 2007). While the adverse impacts of climate change will affect the poor disproportionately, actual impacts will depend at least as much on socio-economic conditions as on the biophysical processes involved.

Farmers were also requested to predict the trend of rainfall in the future. Similar to crop productivity, most farmers were not confident enough to speak about rainfall trend in the future. Majority of them (63\%) believe that the future is not predictable and that only God knows. Such thinking is similar to perception of farmers in the Central Ethiopia (Slegers, 2008): rainfall is beyond men's control and a super natural force (i.e. God act) causes its variability. In the savannah areas farmers are least negative about the future trend with only very few farmers (10\%) out of the average of $15 \%$ believing that rainfall will increase; despite having perceived an increase $(13.4 \%)$ out of the average of $8.7 \%$ over the past decades (Table 3).

\subsection{Farmers' Options to Counter Perceived Trends}

The likelihood function of the Heckman probit model was significant (Wald $\chi 2=7579 \cdot 27$, withP $=0 \cdot 000$ ), showing its strong explanatory power. Additionally, results show that most of the explanatory variables and their marginal values are statistically significant at $\mathrm{P}<0.05$ and generally in the directions that would be expected (Table 5). The calculated marginal effects measure the expected changes in the probability of both perception of climate change and adaptation with respect to a unit change in an independent variable. 


\begin{tabular}{|c|c|c|c|c|}
\hline \multirow[t]{3}{*}{ Dependert variable description } & \multicolumn{4}{|c|}{ Farmers' adaptation status to clir ate change } \\
\hline & \multicolumn{2}{|c|}{ Wet lowland } & \multicolumn{2}{|l|}{ Dry lowland } \\
\hline & Adapted (\%) & Not adapt (\%) & Adapted (\%) & Not adapted $(\%)$ \\
\hline Adaptation (adapted = 1) & 52 & 48 & 44 & 56 \\
\hline Independent variables & Mean & SD & Mean & SD \\
\hline Education of HH head (years) & 2.92 & 1.66 & 2.21 & 1.03 \\
\hline IIII size (number) & 3.38 & 1.35 & 3.29 & 1.28 \\
\hline HH head sex (male - 1) & 0.49 & 0.12 & 0.5 & 0.12 \\
\hline Ferming experience (years) & 12.6 & 6.37 & 8.17 & 4.04 \\
\hline HH bead age (years) & 24.44 & 7.29 & 24.23 & 6.51 \\
\hline Crop income (DRC currency & 1862.35 & 1669.69 & 740.36 & 529.23 \\
\hline Livestock income (DRC cunrency) & 2182.03 & 2731.59 & 2182.03 & 3684.36 \\
\hline Non-farm income (DRC currency & 1885.49 & 2070.02 & 1425.69 & 1055.18 \\
\hline Extension advice (yes $=1$ ) & 0.39 & 0.17 & 0.22 & 0.17 \\
\hline Climute chenge inforration (yes $=1$ ) & 0.33 & 0.28 & 0.22 & 0.28 \\
\hline Cultivated land size (hectares) & 1.24 & 0.94 & 2.14 & 0.6 \\
\hline Plots with steep slope $(\%)$ & 0.28 & 0.28 & 0.11 & 0.06 \\
\hline Plots with $\mathrm{r}$ ixed slope $(\%)$ & 0.28 & 0.28 & 0.44 & 0.06 \\
\hline Semi-fertile plots (\%) & 0.22 & 0.17 & 0.22 & 0.18 \\
\hline Non-fertile plots $(\%)$ & 0.28 & 0.28 & 0.22 & 0.22 \\
\hline Shared out land (ha) & 0.36 & 0.26 & 0.64 & 0.41 \\
\hline Farm-home distance $(\mathrm{km})$ & 1.06 & 0.62 & 1.31 & 0.73 \\
\hline Number of parcels & 1.16 & 0.52 & 1.03 & 0.48 \\
\hline Past knowledge of adaptation (yes $=1$ ) & 0.34 & 0.74 & 0.27 & 0.9 \\
\hline
\end{tabular}

Table 7: Descriptive Summary of Model Variables for Heckman Probit Outcome Model

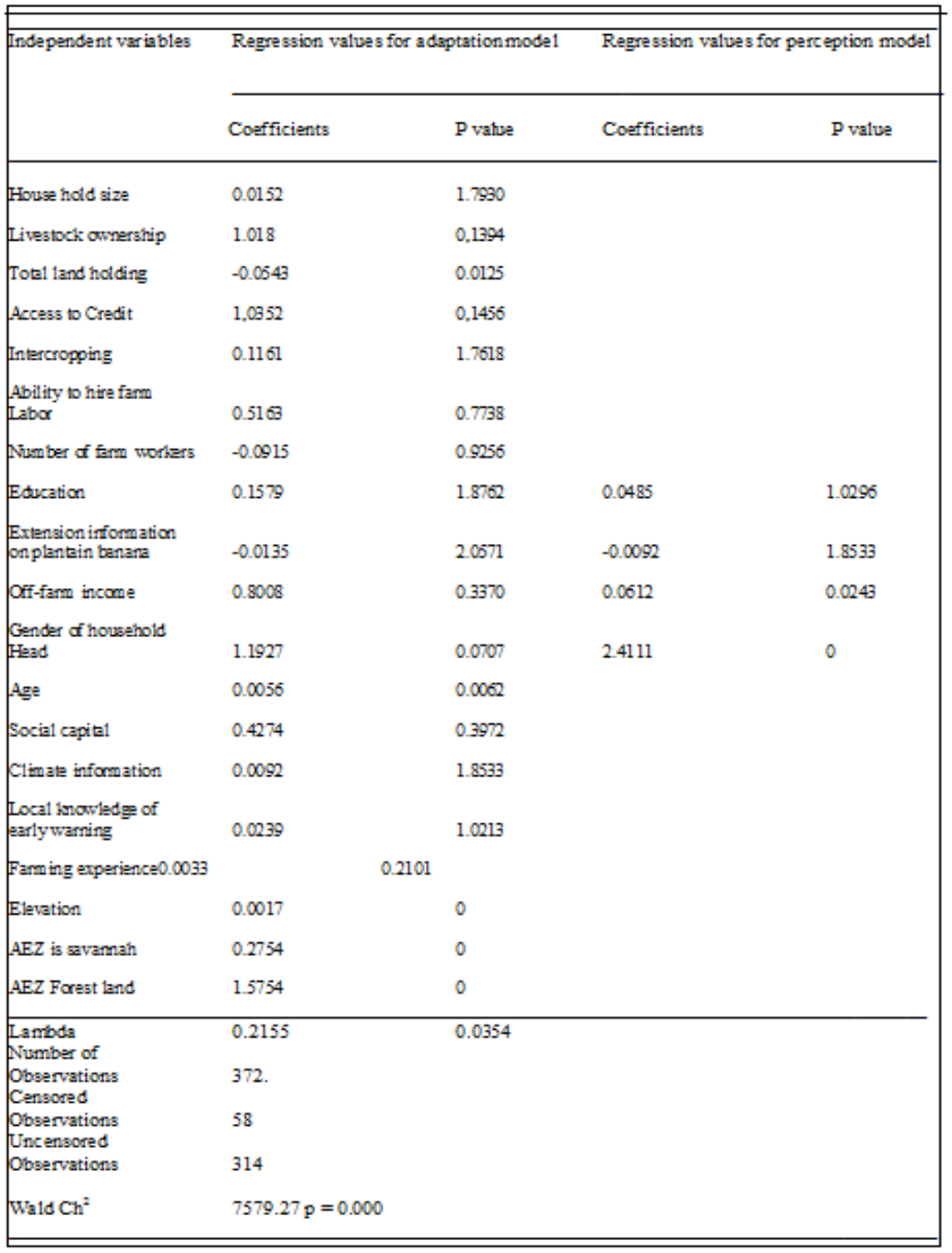

Table 8: Results of the Heckman Prohibit Selection Model (Two-Steps)

With the knowledge that on the one hand most farmers perceive that crop productivity has declined, and on the other hand a perceived decrease in rainfall is seen as the main cause of yield reductions, this study focused on the farmers' strategies to cope with these perceptions. Such strategies are divided into coping strategies and adaptation strategies. Coping strategies are short-term and unplanned in response to unexpected crop failure and yield losses and just for survival, while adaptation strategies are long-term and planned responding to expected continued decline or uncertainty in future crop productivity and food production (Stern, 2007). Strategies mentioned by farmers during the survey were categorized into coping and adaptation strategies based on the definitions mentioned above. 


\subsubsection{Coping Strategies}

Over decades, where rainfall variability impacts most strongly on livelihoods, farmers have developed coping strategies to buffer against the uncertainties of crop yield induced by annual or seasonal variation in rainfall. Table 4 shows the different coping strategies to unexpected crop failure and low yields in the study area.

Most households (64\%) revert to small-scale mining as a short-term coping strategy during abrupt crop shortage as a result of climate change and variability. It ranges from $65 \%$ of households in forest dominated land to $63 \%$ in savannah dominated landscape.

Accessing relief programmes: Relief in the form of cash or food is a common aid provided basically by nongovernmental organizations in the study area in the form of food-for-work or free distribution. Generally, 54.5\% of households have received relief from non-governmental organizations working in the areas.

Accessing credit: Credit refers to advances, either in cash or as farm inputs to farmers and to be repaid at a later agreed-upon date. Farmers can access credit from nongovernmental organizations during crop failure. Generally, an average of $60.5 \%$ of respondents perceived the use of credit facilities, with the highest percentage in savannah land where $68 \%$ of farmers mentioning the micro credit access as appropriate coping strategy. These households were close to Kipupu, Tulambovillages where they are often involved in petty trading, and can repay the money. According to farmers, they have also received credit in the form of seeds to compensate seed shortage. Other form of credit access comprises livestock activity to compensate crop failure, thus playing a crucial role in poverty reduction and rural development in Africa (IUCN, 2010). Firstly, 'livestock provide cash income or income in kind through the sale of animals and / or the sale and consumption of milk, meat, eggs and other animal products'. Secondly, 'livestock are a form of savings (capital growth through herd growth) and insurance, as the sale of animals provides immediate cash to deal with significant or unexpected expenditures (for example, school or medical fees)'. Thirdly, 'livestock provide manure, draft power and transport services, which can be used on the household farm or exchanged on the market (for example, rental of bull for ploughing)'. Finally, "being a source of wealth, livestock not only contribute to social status but may possibly facilitate access to financial services, both in formal and informal markets'. With that background several authors argue that, safeguarding and increasing the poor's returns from their livestock assets is expected to help them in their endeavor to escape poverty (Brown, 2003; Delgado, 2003; Catley, 2008).

Using the traditional social security system: This system is one of the most important social security strategies to help each other. The system works within extended family and kinship networks where there is compulsory sharing of resources. In the case of crop failure, members with grains or cash reserves share with less endowed members.

Charcoal production $(32,35 \%)$ was used as a coping strategy in both forest and savannah areas, thus having adverse effect on the conservation of the Itombwe nature reserve. According to Ford et al., (2014), communities can also cope up to climate variability and change by accessing alternative natural resources from forests such as charcoal burning and selling.

\subsubsection{Adaptation Strategies}

In addition to coping strategies, farmers have several adaptation strategies in response to uncertainty and expected declining crop productivity (Table 4).

Change in crop variety: Farmers change varieties of a given crop depending on the rainfall conditions (Deressa et al. 2009). Changes mainly concern a shift from long to short duration varieties; in the study areas particularly for maize. Maize (Zea mays L.) variety in high yielding with a long growing period while variety with low yielder with short duration. Cassava (Manihot esculentaCrantz, Family Euphorbiaceae) is a staple food for more in the study area. It's cultivated for root tubers, leaves and its potential yield under various environments. Cassava bacterial blight (CBB) incidence was cited in study area. However, Cassava mosaic disease (CMD) was mentioned to be the most important in recent years. The improved variety "Sawasawa" has then been most cultivated due to high quality of cassava flour compared to other new improved varieties and is actually cultivated by more than $80 \%$ of farmers who are cultivating new varieties. Following the severe cassava mosaic pandemic, improved CMD-resistant varieties were released and widely disseminated in affected area, unfortunately, local CMD-susceptible varieties didn't completely disappear because of farmers' preferences to their quality (Bisimwa et al. 2019).

Adjusting planting dates: Adjusting planting dates as a strategy in response to seasonal variation in rainfall has been reported in Ethiopia and South Africa (Bryan et al. 2009) and in Burkina Faso (West et al. 2008). In our research farmers told they had approximately fixed planting dates when rainfall was reliable. However, nowadays, they follow the pattern of rainfall and adapt to expected rainfall. Some $23.05 \%$ of respondents reported that adjusting planting dates based on the onset of both wet and dry season is an adaptation strategy to rainfall variability. This is more evident in savannah dominated areas where rainfall is much lower and more disperse. Women were more active in this area. An increase in the participation of women and girls in agriculture, for example, has become a priority not simply because of their importance to global food systems but because women, more so than men, are still impeded in their opportunities by formal and informal gendered systems of access and control of productive resources. There is an emerging consensus within the donor community that the effects of climate change on men and women will be different, and that awareness of the consequences of these differences can and should be incorporated into program design and implementation. The differential impacts will affect men's and women's time labor, access to other productive assets, and will require sitespecific responses as well as gender-sensitive policies.

Diversifying income through off-farm activities: Households diversify income from different sources particularly from off-farm activities. These include petty trading, preparation of local drinks (e.g., Kanyanga) and engaging in unskilled 
labor selling (handicraft work, charcoal production, retail business, etc..). Almost one-third of the interviewed farmers are engaged in off-farm activities.

\subsubsection{Income Sources}

Food security is an integral part of people's well-being. Sustainable livelihood approaches have indicated that there are other important factors that influence people's livelihoods, such as income, health, and assets. In addition to the aforementioned adaptation strategies, communities in the Itombwe region attempted to be involved in various incomegenerating activities. Income from livestock is among multiple sources that support the livelihoods of rural communities. The contribution of livestock accounted for about $45.7 \%$ of the total income in savannah and $33.3 \%$ of the total income in the forest habitat. In order to estimate the net income generated from livestock, all expenses made for purchasing fodder, payments for hired labor and fees for veterinary services were deducted from total gross income. All components of livestock income sources such as sales of live animals, milk, butter oil, hides and skins were accounted for.

A total of 52 pastorals, 23 semi-pastorals, 39 agro pastoral and 49 mixed-farming communities generate income from selling firewood and charcoal, accounting for about $4.1 \%$ of the total income and implying reliance on exploiting the natural forests for energy and commercial purposes. This may be taken as an indication of how income constraints can pressure rural people to keep on selling firewood and charcoal to meet their short-term needs without considering the long-term burdens on the natural resource base. Hence, continual damage of the natural forest can accentuate the negative effects of climatic change in the area. In this context, the key informants further recommended urgent measures to enable the fuel-wood sellers to shift to compatible income diversification alternatives like honey, salt mining, commercial tree plantation, livestock rearing and trading, which are eco-friendly livelihood alternatives. Similar conclusions made by Habibah et al. (2010) indicate that locals can be active participants in protecting the natural resources if they find that they could maintain their long-term benefits in sustainable ways.

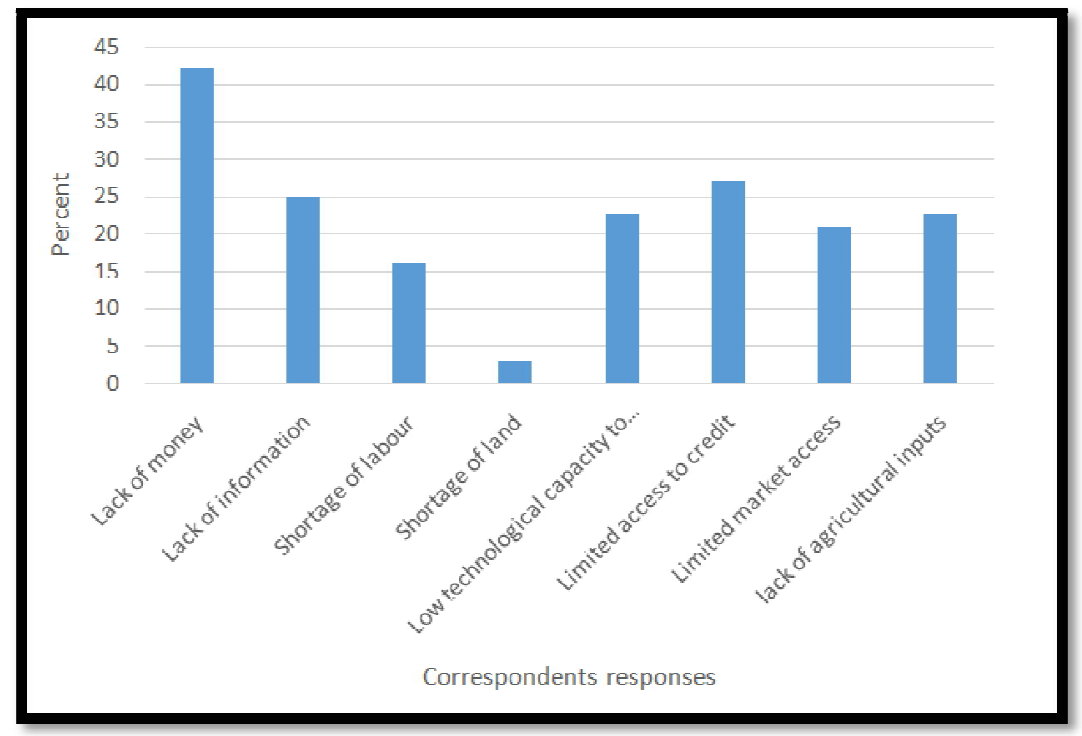

Figure7. Barriers to Adaptation in Itombwe Massif

\subsection{Barriers to Adaptation}

The results indicate that $38.8 \%$ of the surveyed farmers have observed increasing temperature over the past 10 years were as $40 \%$ of them have observed decreasing rainfall over the past 10 years (Table 1 and 2). Additionally, these farmers who claimed to have observed changes in climate over the past 10 years were subsequently asked if they have responded through adaptation to counteract the impact of the climate change. Accordingly, those who responded that they have adapted to climate change indicate different adaptation strategies (Table 4). These adaptation measures mentioned by Itombwe massif farmers are similar to the other findings in the climate change adaptation literature (Maddison, 2006; Nhemachena and Hassan, 2007; Hassan and Nhemachena, 2008; Kurukulasuriya and Mendelsohn, 2008). However, smallholder farmers who did not adapt have given many reasons for their failures to adapt which include lack of money $(42 \%)$, lack of credit access (27\%), lack of information (25\%), lack of agricultural input (22.5\%), and limited market access (21\%)(Figure.7).

All these farmers' constraints are linked with poverty. Lack of money hinders farmers from utilizing necessary resources and technologies for adaptation. Lack of labor or money hire labor influence their capacity to adapt climate change. Shortage of land associated with high population pressure plays a great role in diminishing their potential to adapt. Low technological capacity to innovation associated with lack of water resources and technologies. Lack of market access is related with poor transportation link of the area to the town nearby. Lack of credit access and agricultural inputs are highly associated with lack of institutional support. Lack of information to adaptation could be associated with various factors including lack of institutional support and research related with climate change and adaptation. The findings also corroborate other studies that suggest that for rural small-scale farmers who have poor access to resources, vulnerability to climate change and variability are compounded by lack of road infrastructure and access to vibrant markets (Bunting et 
al. 2013). This situation is likely to worsen, with climate change predicted to disrupt road infrastructure in Itombwe massif region (Chinowsky et al. 2013).

Climate change is expected to have a significant impact on Itombwe massif region, including increases in average temperature and rainfall. However, there is considerable uncertainty surrounding rainfall projections and indications that there will be a great deal of regional variation in precipitation across the region. Moreover, little can be said about future changes in the frequency of extreme events such as drought and flood (Herrero et al. 2010). Smallholder producers, therefore, must make decisions in an environment of great uncertainty. This research shows that despite limited evidence of climate change, farmers and pastoralists do indeed perceive the climate to be changing and are particularly concerned with perceived changes in rainfall variability. Perceptions of climate change appear to be mainly based on farmers' experience (WWF-Itombwe, 2013) - those who had been involved in farming longer were more likely to perceive longterm changes in temperature, precipitation, and rainfall variability. Farmers are taking measures to protect their livelihoods against perceived changes in climate, however, many households face considerable challenges in adapting to climate change.

The rural poor need more support from the government, NGOs, and the private sector to enable them to move beyond short-term coping measures in response to climate shocks and to invest in long-term, anticipatory strategies that enhance resilience to climate change through the accumulation of assets, livelihood diversification, and the adoption of agricultural technologies that allow for increased productivity and profitability. This is particularly true in arid areas, where households face greater constraints in adapting to climate change and have limited options to increase resilience to future climate change. However, in addition to providing a safety net following major climate shocks, more should be done to build the resilience of these communities to withstand future climate crises. In general, the results emphasize the need for greater investments in rural and agricultural development to support the ability of households to make strategic longterm decisions that affect their future well-being. Autonomous adaptation is insufficient to address the threats posed by climate change.

While farmers have made adjustments to their farming practices in response to climate change (in particular, changing planting decisions), few of them are able to make large investments to reduce their vulnerability, for example in agroforestry or irrigation in savannah habitat, although there is a desire to invest in such measures. In the case of agroforestry, those farmers who are able to make the investment appear to have greater access to resources (such as nonfarm income), social networks, and information through extension services. Even changing crop varieties, the most common, less costly, adaptation faces obstacles, including lack of suitable agricultural inputs and poor access to extension services. In addition, there is some indication that access to improved seeds may be problematic. This may be due to the fact that some households rely on traditional seed sharing and storage systems through local networks, but also to the fact that seed sold on rural markets is often of poor quality and improperly labeled. At the same time, rainfed agriculture is and will remain the dominant source of staple food production and the livelihood foundation of the majority of the rural poor in Itombwe massif region (Herrero, 2010). From that prospect, there is an urgent need to improve the scientific and economic capacity to better understand and cope with existing climate variability. Therefore, a better understanding of farmers' perceptions of climate change, ongoing adaptation measures, and the decision-making process is important to inform policies aimed at promoting successful adaptation strategies for the agricultural sector in the Itombwe massif region.

\section{Conclusion and policy implications}

Thereisagrowingconsensusthatoverthecomingdecades, higher temperature and changing precipitation levels caused by climate change will depress crop yields in many countries. This is particularly crucial in low-income Itombwe massif region, where adaptive capacity is perceived to be low (IPCC, 2007a). Thus, understanding farmers' responses to climatic variation is crucial in designing appropriate coping strategies to climate change.

Smallholder farmers are taking measures to protect their livelihoods against perceived changes in climate. However, many households face considerable challenges in adapting to climate change. While farmers have made adjustments to their farming and livestock rearing practices in response to climate change (in particular, changing planting decisions), few of them were able to make large investments to reduce their vulnerability. The novelty of this paper lies in its exploration of the perceptions of stressors on rural livelihoods across multiple scales. This research adds weight to the claim that vulnerability reflects multiple forces and processes, and that multiple stresses, that are agroecological, socioeconomic, and institutional in nature, need to be examined to understand vulnerability and to prevent maladaptation.

Smallholder farmers in the two parts of the study area were found to be broadly similar with respect some variables that affected perception and adaptation to climate change. They have also considerable differences in terms of the direction and effect of many of the explanatory variables that affect perception and adaptation. Results of the ordered logit regression analysis showed that farmer's adaptive capacity to the innovation is determined by educational level of the household head, and availability of technology. While education enhances the probability of adapting for those with low adaptive capacity, technology enhances the probability of adapting for those with high adaptive capacity.

Farmers manage risks, including those related to climate, regularly as part of their everyday lives. However, there is a need for farmers not only to cope with the impacts of a changing climate but rather to adapt in order to reduce the negative impact of climate change. Socioeconomic and environmental factors have a big role to play in the way farmers perceive and later adapt to impacts of a changing climate (Deressa et al. 2011). Besides coping strategies to protect farmers against climate related hazards in this survey, factors that hindered adaptation included poverty (inability to pay 
for farm inputs, equipment and services like labor), unreliable weather forecasts, and shortage of food to store, among others.

The findings from this paper have important implications for policy and practice. Firstly, there is the need to incorporate non-climatic or socioeconomic stressors into climate change adaptation policy formulation in dryland farming systems. Second, operational rules, with their high transaction costs for small farmers and foresters in particular, must be streamlined. Understanding what constitutes a stress on rural livelihoods is critical in designing and prioritizing effective adaptation policies. Secondly, the mismatch between district level and local level perceived stressors on rural livelihoods could result in incorrect policy interventions and misapplication of scarce resources. While not downplaying the significance of managing the adverse impacts of climate change on agrarian livelihoods, this study has highlighted the significance of tackling both climatic and non-climatic stressors. Tackling non-climatic stressors will invariably enhance the capacity of farming households to confront the challenges posed by climatic change on food security and livelihoods.

The results of this study also show that lack of experience, lack of access to information on climate change and lack of education limit perception and adaptation decision of smallholder farmers. Hence, facilitating effective and reliable access to information and improving farmers' awareness of potential benefits of adaptation are found to be important policy intervention measures. Climate change communication provides an avenue through which perceptions of resource users can be integrated in climate change adaptation projects. This would facilitate exchange of climate change information between smallholder farmers on one hand and donors and sustainable agriculture project implementers on the other. It would also provide additional climatic information that would enable farmers relate to sustainable agriculture as an adaptation strategy. We conclude that policy-makers must create an enabling environment to support adaptation by increasing access to information, credit and markets, and make a particular effort to reach small-scale subsistence farmers, with limited resources to confront climate change.

Food insecurity is a major problem that affects most households in the Itombwe massif as well as elsewhere across South Kivu province (Gaye, 2005). Most of the households in the study communities engaged in subsistence agriculture to feed their immediate family members, and there were several instances of food insecurity directly linked to rainfall variability. This situation is, perhaps, attributable to the over-dependence of these study communities on rain-fed agricultural systems. Hence, the duration, timing and amount of rainfall directly determines crop productivity. Further investigation of farmers' perceptions of the weather could be explored in view of the influence that farmer-weather relationships have on farmers' perceptions of climate change, and the possible barriers or facilitation to adaptive capacity. The influence of farmer-weather relationships upon the specific development of adaptive capacity is a future avenue of research that could generate significant answers of the known gap between knowledge and adaptations surrounding farmers' responses to climate change.

With reference to the above conclusion, this study raises the following policy implications:

- Improved access to climate forecasting and dissemination to ensure and that farmers have access to affordable credit schemes to increase their ability and flexibility to adopt adaptation measures in response to the forecasted climate conditions;

- $\quad$ Research and Development and introduction of more new crops/varieties that more adaptive to harsh climatic conditions;

- Extension services are inadequate in the study area, improving the knowledge and skills of extension service personnel and making the extension services more accessible to farmers appear to be a key element of a fruitful adaptation in the study area;

- Provision of necessary technical and financial support to enhanced monitoring capabilities because of the diversity of climatic and environmental conditions especially seasonality and high annual variability of rainfall and temperature;

- Explore the options and benefits for mitigation strategies in the livestock sector, particularly where there are opportunities to access carbon finance payments, and identifying synergies between productivity and environmental benefits, for example through reduced methanogenesis (lower methane reduction leading to increased fed conversion efficiency), reforestation of rangelands, manure management, or restoration of degraded rangelands;

- Strengthen understanding of appropriate approaches to improved pasture management that accommodate climatic flux, based on the principles of mobility, fluctuating herd sizes, and diverse livestock species, and identify technological options, such as satellite imagery, for regulation of transhumance and landscape-scale seasonal resource management. 6. Based on improved understanding of pasture management, identify opportunities for livestock keepers to secure carbon credits for improved rangelands management;

- investment in education systems and creation of off-farm job opportunities. Wide dissemination and promotion of the application of information, including weather and climate information at various levels (down to the community level), to support the implementation of adaptation activities through investment in education systems of off-farm job opportunities in the area as a policy option regarding reduction of the adverse impacts of climate change in the study area;

- Finally, the Government should invest much in climate-dependent livelihoods. Such investments should target locations where agriculture-based livelihoods are under most pressure from climate variability and change and other environmental and social developments like theltombwe massif mountains study area. 


\section{References}

i. Adger, W.N. (2006). Vulnerability.Glob Environ ChangVol. 16(3), 268-281.

ii. Adger, W.N., Huq, S., Brown, K., Conway, D., Hulme, M. (2003). Adaptation to climate change in the developing world, Progress in Development Studies 3, 179-195.

iii. AgMERRA Dataset. (2019). MERRA-NASA, corrected by AgMIP.

iv. Anley, Y., Bogale, A. and Haile-Gabriel, A. (2007). Adoption decision and use intensity of soil and water conservation measures by smallholder subsistence farmers in Dedo district, Western Ethiopia, Land Degradation and Development18, 289-302.

v. Asfaw, A. andAdmassie, A. (2004). The role of education on the adoption of chemical fertilizer under different socioeconomic environments in Ethiopia. Agricultural EconomicsVol. 30(3), 215-228.

vi. Asrat, P, Simane, S. (2017). Adaptation benefits of climate-smart agricultural practices in the Blue Nile Basin: empirical evidence from North-West Ethiopia. In: Filho WL, Belay S, Kalangu J, Menas W, Munishi P, Musiyiwa $\mathrm{K}$ (eds) Climate change adaptation in Africa: fostering African resilience and capacity to adapt. Vol. 1. Springer International Publishing AG, Cham, Switzerland.

vii. Bardsley, D. K.and Wiseman, N. D. (2012). Climate change vulnerability and social development for remote indigenous communities of South Australia. Global Environment Change 22, 713-723.

viii. Bashaasha, B., Waithaka, M. andKyotalimye, M. (2010). Climate change vulnerability, impact and adaptation strategies in agriculture in Eastern and Central Africa.

ix. Bayard, B., Jolly, C.M. and Shannon, D.A. (2007). The economics of adoption and management of alley cropping in Haiti. Journal of Environmental Management 84, 62-70.

x. Bekele, W. and Drake, L. (2003). Soil and water conservation decision behavior of subsistence farmers in the Eastern Highlands of Ethiopia: a case study of the Hunde-Lafto area.Ecological Economics46, 437-51.

xi. Birungi, P., Hassan and Poverty, R. (2010). property rights and land management in Uganda. African J Agricult Res EconomicsVol. 4 No 1, 48-69.

xii. Bisimwa, E.B., Birindwa, D.R., Yomeni, M.O., Rudahaba, N., Byamungu, K. and Bragard, C. (2019). Multiple Cassava Viruses' Co-Infections and Resurgence of Pests Are Leading to Severe Symptoms and Yield Losses on Cassava in the South-Kivu Region, Democratic Republic of Congo.American Journal of Plant Sciences 10, 19691988.

xiii. Brown, A.G. (ed.) (2003). The livestock revolution: a pathway from poverty? Proceedings of a conference held at the ATSE Crawford Fund, Parliament House, Canberra. (Canberra : ATSE Crawford Fund).

xiv. Bryan, E., Deressa, T., Gbetibouo, A. and Ringler, C. (2009). Adaptation to climate change in Ethiopia and South Africa: options and constraints.Environ. Sci. Policy 12, 413-426.

xv. Bryman, A. (2008). Social Research Methods (3rd ed.). Oxford: Oxford University Press, USA.

xvi. Cabrera, V.E., Solís, D., Baigorria, G.A., Letson, D. Managing climate variability in agricultural

xvii. analysis. In: Long, J. A. and Wells, D. S. (Eds). In: Long J.A., Wells D.S. (eds.)

xviii. Ocean Circulation and El Niño: New Research. 2009, s. 163 - 179.

xix. Bunting, E., Steele, J., Keys, E., Muyengwa, S., Child B. and Southworth, J. (2013). Local perception of risk to livelihoods in the semi-arid landscape of Southern Africa. Land 2, 225-251.

xx. Bucekuderhwa, C. et Mapatano, S. (2013). Comprendre la dynamique de la vulnérabilité à l'insécurité. VertigO la revue électronique en sciences de l'environnement, 1-29.

xxi. Bucekuderhwa, C. et Ngendakuriy. (2011). Technological change and subsistence farming: A two stage optimal control approach, Working paper.

xxii. Catley, A. (2008). The growing demand for livestock. Will policy and institutional changes benefit poor people? ID21 Insights, 72, pp. 1-2.

xxiii. Chinowsky, P., Schweikert, A., Strzepek, N., Manahan, K., Strzepek, K., Schlosser, CA. (2013). Climate change adaptation advantage for African road infrastructure. Clim Change 117, 345-361.

xxiv. Collar, N. J. and Stuart, S. N. (1988). Key forests for threatened birds in Africa. ICBP and IUCN, Cambridge, UK, pp.102.

xxv. Dejene, K. M. (2011). Farmers' perception and knowledge of climate change and their coping strategies to the related hazards: Case study from Adiha. Central Tigray, Ethiopia.Agricultural sciencesVol. 2(2), 138-145.

xxvi. Delgado, C. (2003). Rising Consumption of Meat and Milk in Developing Countries Has Created a New Food Revolution.Journal of NutritionVol. 13(3), 3907-3910.

xxvii. Deressa, T. T., Hassan, R. M. and Ringler, C. (2011). Perception of and adaptation to climate change by farmers in the Nile basin of Ethiopia.Journal of Agricultural Science 149, 23-31.

xxviii. Deressa, T.T., Hassan, R.M., Ringler, C., Alemu, T., Yusuf, M. (2009). Determinants of farmers' choice of adaptation methods to climate change in the Nile Basin of Ethiopia.Glob. Environ. Change19, 248-255.

xxix. Dessai, S., Hulme, M., Lempert, R. and Pielke Jr, R. (2009). Climate prediction: a limit to adaptation. Adapting to Climate Change.Thresholds, Values, Governance,64-78.

xxx. Dolisca, F., Carter, R.D., McDaniel, J.M., Shannon, D.A. and Jolly, C.M. (2006). Factors influencing farmers' participation in forestry management programs: A case study from Haiti",Forest Ecology and Management Vol. 23(6), 324-331.

xxxi. Doumenge, C. (1998). Forest Diversity, Distribution, and Dynamique in the Itombwe Mountains, South-Kivu, Congo Democratic Republic.Mountain Research and Development Vol. 18(3), 249-264. 
xxxii. Doumenge, C. and Schilter, C. (eds.), (1997). Les Monts Itombwe. D'une enquête environnementale et socioéconomique à la planification d'interventions au Zaïre. IUCN, Brazzaville, pp. 270.

xxxiii. Doumenge, C. (1990). La conservation des écosystèmes forestiers du Zaïre. IUCN, Gland, Switzerland. pp. 242.

xxxiv. FAO. (2007). The roles of agriculture in development: policy implications and guidance. Research programme summary report 2007. Socio-economic analysis and policyimplications of the roles of agriculture in developing countries, Rolesof AgricultureProjectPhaseII. Rome.

xxxv. Feder, G, Just, R. and Zilberman, D. (1985). Adoption of agricultural innovations in developing countries: A survey.Economic Development and Cultural ChangeVol.33(2), 255-98.

xxxvi. Ford, J.D., Berrang-Ford, L., Bunce, A., McKay, C., Irwin, M. and Pearce, T. (2014). The status of climate change adaptation in Africa and Asia. Reg Environ Change 15, 801-814.

xxxvii. Fosu-Mensah, B. Y. (2011). Modelling maize (Zea mays L.) productivity and impact of climate change on yield and nutrient utilization in sub-humid Ghana. PhD Dissertation, Kwame Nkrumah University of Science and Technology, Kumasi, Ghana.

xxxviii. Fosu-Mensah, B., Vlek, P., andManschadi, M. (2010). Farmers' Perceptions and Adaptations to Climate Change: A Case Study of Sekyedumase District in Ghana. A contributed paper presented at World Food Systems Conference in Tropentag, Zurich.

xxxix. Gaye, D. (2005). Pauvreté et insécurité alimentaire au Sud-Kivu. Situation des milieux précarisés à l’Est de le République Démocratique du Congo.

xl. Gbetibouo, A.G. (2009). Understanding farmers' perceptions and adaptations to climate change and variability. The Case of the Limpopo Basin, South Africa. IFPRI Discussion Paper 00849.

xli. Gebreyes, M., Zinyengere, N., TheobaldTheodory, F. Speranza, F. (2017). Introduction: Grounding Climate Change, Vulnerability, and Adaptation in Africa. In beyond agricultural impacts multiple perspectives on climate change and agriculture in Africa edited by Zinyengere, N., Theobald Theodory, F., Gebreyes, M. and Speranza Ifejika, Academic Press is an imprint of Elsevier. pp. 1-9.

xlii. Habibah, A., Hamzah, J. and Mushrifah, I. (2010). Sustainable Livelihood of the Community in TasikChini Biosphere Reserve: The Local Practices.Journal of Sustainable DevelopmentVol. 3(3), 184-196.

xliii. Hassan, R. andNhemachena, C. (2008). Determinants of African farmers' strategies for adapting to climate change: multinomial choice analysis.Afr J Agric Resour Econ 2, 3-104.

xliv. Heckman, J.J. (1976). Common structure of statistical models of truncation, sample selection and limited dependent variables and a simple estimator for such models.Ann Econ Soc Meas 5, 475-492.

xlv. Herrero, M., Ringler, C., van de Steeg, J., Thornton, P., Zhu, T., Bryan, E., Omolo, A., Koo, J., Notenbaert, A. (2010). Climate Variability and Climate Change and Their Impacts on Kenya's Agriculture Sector. International Livestock Research Institute (ILRI), Nairobi, Kenya

xlvi. Houghton, J. T., Ding, y., Griggs, D.J., Noguer, M., van der linden, P. J., Dai, X., Maskell, K. \& Johnson, C. A. (2001). Climate Change 2001: The Physical Basis". Contribution of Working Group I to the Third Assessment Report of the Intergovernmental Panel on Climate Change, 2001. Cambridge, UK : Cambridge University Press.

xlvii. IAC (INTER ACADEMY COUNCIL). (2004). Realizing the Promise and Potential of African Agriculture. Amsterdam, The Netherlands: Inter Academy Council.

xlviii. IPCC. (2007a). Climate Change 2007: Impacts, Adaptation and Vulnerability. Cambridge : Cambridge University press.

xlix. IPCC. (2007b). Climate Change: Synthesis Report. Contribution of Working Groups I, II and III to the Fourth Assessment Report of the Intergovernmental Panel on Climate Change. Geneva : Intergovernmental Panel on Climate Change.

l. IPCC. 2001, Climate Change. (2001). Impacts, adaptation, and vulnerability, intergovernmental panel on climate change. Cambridge : Cambridge University Press.

li. IUCN (International Union for Conservation of Nature) (2010). Building climate change resilience for African livestock in sub-Saharan Africa - World Initiative for Sustainable Pastoralism', (WISP): a program of IUCN - The International Union for Conservation of Nature, Eastern and Southern Africa Regional Office, Nairobi, March 2010, viii + 48pp.

lii. Jayne, T.S., Mather, D. and Mgheny, E. (2010). Principal Challenges Confronting Smallholder Agriculture in SubSaharan Africa.World DevelopmentVol. 38(10),1384-1398.

liii. Jagtap, S. (2007). Managing vulnerability to extreme weather and climate events: Implications for agriculture and food security in Africa. Proceedings of the International Conference on Climate Change and Economic Sustainability held at Nnamdi Azikiwe University, Enugu, Nigeria, pp 45-52.

liv. Kandlikar, M., Risbey, J. andDessai, S. (2005). Representing and communicating deep uncertainty in climatechange assessments",GeoscienceVol. 337(4), 443-455.

lv. Kebede A., Hasen A. and Negatu, W. (2011). A comparative analysis of vulnerability of pastoralists and agropastoralists to climate change: a case study in Yabello Woreda of Oromia Region, Ethiopia.Ethiop J Dev ResVol. 33(1), 61-95.

lvi. Kurukulasuriya, and Mendelsohn. (2008). A Ricardian analysis of the impact of climate change on African cropland.African Journal of Agricultural and Resource EconomicsVol. 2 No.1, pp. 1-23.

lvii. Laurent, R. F. (1964). Adaptive modifications in frogs in an isolated highland fauna in Central Africa.Evolution $18,458-467$. 
lviii. Likert, R. (1974). A method of constructing an attitude scale. In: GM Maranell (eds) Scaling a Sourcebook for Behavioral Scientists, Chicago, USA: Aldine Publishing Company, pp. 233-243.

lix. Lodoun, T., Giannini, A., Traore', P.S., Some', L., Sanon, M., Vaksmann, M., Rasolodimby, J.M. (2013). Changes in seasonal descriptors of precipitation in Burkina Faso associated with late 20th century drought and recovery in West Africa.Environ. Dev 5, 96-108.

lx. Lukuli. (2006). Mesure et analyse de la pauvreté au Sud-Kivu, LEAD, Projet PIC « Dynamique des filières productives et développement rural intégré », CUD, Document de travail, miméo, LEAD, UCB.

lxi. Maddison, D. (2006). The Perception of and Adaptation to Climate Change in Africa. CEEPA. Discussion Paper No. 10. Centre for Environ. Economic and Policy in Africa. Univer. of Pretoria, Pretoria, South Africa.

lxii. Mary, A. L. and Majule, A. E. (2009). Impacts of climate change, variability and adaptation strategies on agriculture in semi-arid areas of Tanzania: The case of Manyoni District in Singida Region, Tanzania.African Journal of Environmental Science and Technology Vol. 3(8),206-218.

lxiii. McCarthy, J., Canziani, O.F., Leary, N.A., Dokken, D.J., White, C. (Eds.). (2001). ClimateChange 2001 : Impacts, Adaptation, and Vulnerability. Contribution of Working Group II to the Third Assessment Report of the Intergovernmental Panel on Climate Change. Cambridge University Press, Cambridge.

lxiv. Meze-Hausken, E. (2004). Contrasting climate variability and meteorological drought with perceived drought and climate change in northern Ethiopia.Climate Research 27, 19-31.

lxv. Mubalama, L., Igunzi, F. Buhendwa, G. (2020). Local community perceptions towards biodiversity conservation within protected areas: Implications for policy making and management in Itombwe Nature Reserve, Eastern DR Congo.IOSR Journal of Environmental Science, Toxicology and Food TechnologyVol. 14(4), 26-48.

Ixvi. Mubalama, L. (2018). Statut et Gestion des aires protégées. Collection : "Cours". Les Editions de l’Université Officielle de Bukavu - Ed. -UOB. 320 pp. ill., 21 x $15 \mathrm{~cm}$.

lxvii. Mubalama, K., Igunzi, A., Banswe, T., Asesa, L. et Kavusa, K. (2018). Savoirs traditionnels conciliés aux connaissances scientifiques comme nouveau paradigme de la conservation des aires protégées : Cas des Malambo (Réserve Naturelle d'Itombwe). Annales des Sciences et Sciences Appliquées Vol. 4 No, (3/4), $127-144$.

lxviii. Newing, H. (2011). Conducting research in conservation: a social science perspective. Routledge, England.

lxix. Nwafor, J.C. (2007). Global climate change: The driver of multiple causes of flood intensity in Sub-Saharan Africa', Paper presented at the International Conference on Climate Change and Economic Sustainability held at Nnamdi Azikiwe University, Enugu, Nigeria.

lxx. Nhemachena, C. (2009). Agriculture and Future Climate Dynamics in Africa: Impacts and Adaptation Options, Pretoria: University of Pretoria.

lxxi. Nhemachena, C. and Hassan, R. (2007). Micro-level analysis of farmers' adaptation to climate change in Southern Africa. IFPRI Discussion Paper No. 00714. International Food Policy Research Institute, Washington, DC.

lxxii. Omari, I., Hart, J. A., Butynski, T. M., Birhashirwa, N. R., Agenonga, U., Yuma, M., Bengana, F., Bashonga, M, and Bagurubumwe, N. (1999). The Itombwe Massif, Democratic Republic of Congo: biological surveys and conservation with an emphasis on Grauer's gorilla and birds endemic to the Albertine Rift. Oryx Vol. 33, 301322.

lxxiii. République Démocratique du Congo/Ministère de l'agriculture. (2008), Le Code agricole. L'outil majeur pour organiser le développement durable en RD Congo. pp.50.

lxxiv. Prigogine, A. (1985). Conservation of the Avifauna of the forests of the Albertine Rift. In, Diamond, A. W. and Love- joy, T. E. (eds.), Conservation of tropical forest birds. ICBP Technical Publication, 4 : pp. 277-2.

lxxv. Prigogine, A. (1984), Les oiseaux de l'Itombwe et de son hinterland. Volume III. Annales du Musée Royal d'Afrique Centrale, Sciences Zoologiques, 243, pp.146.

lxxvi. Prskawetz, A., Winkler-Dworak et M.G. Feichtinge. (2003). Production, distribution and insecurity of food: a dynamic framework.Structural Change and Economic DynamicsVol.14, 317-337.

lxxvii. Slegers, M.F.W. (2008). Exploring Farmers' Perceptions of Drought in Tanzania and Ethiopia" (Doctoral Thesis). Wageningen University, The Netherlands.

lxxviii. Songok C.K., Kipkorir, E.C., Mugalavai, E.M. (2011). Integration of indigenous knowledge systems into climate change adaptation and enhancing food security in Nandi and Keiyo districts, Kenya". In: Filho WL (ed) Experiences of climate change adaptation in Africa. Springer, Hamburg, pp 69-95.

lxxix. SPSS. (2017). Statistical Package for Social Sciences (SPSS): Advanced Statistics Version 25. IBM Corp. Released 2017. IBM SPSS Statistics for Windows, Version 25.0. Armonk, NY: IBM Corp.

lxxx. Stern, N. (2007). The economics of climate change: The Stern Review. Cambridge, UK, Cambridge University Press.

Ixxxi. UNDP. (2007). Human Development Report 2007-2008, New York.

lxxxii. UNFCCC. (2003). Bali Action Plan-UN Framework Convention on Climate Change.

lxxxiii. USAID. (2007). Adapting to Climate Variability and Change: A Guidance Manual for Development Planning. USAID. Washington, D.C.

lxxxiv. West, C.T., Roncoli, C. and Ouattara, F. (2008). Local perceptions and regional climate trends on the central plateau of Burkina Faso. Land Degrad. Dev. 19, 289-304. WFP (World Food Programme), 2010. Fighting hunger worldwide: measuring results and sharing lessons. Annual Evaluation Report 2010.

lxxxv. World Bank. (2008). World Development Report 2008. World Bank, Washington DC. 
lxxxvi. WWF-Itombwe. (2013). Réduction des gaz à effet de serre et évaluation de l'adaptation des communautés face au changement climatique dans et autour de la Reserve Naturelle d'Itombwe. Project Agreement Number: FY13/CD000501/05.

lxxxvii. Yirga, C. T. (2007). The dynamics of soil degradation and incentives for optimal management in Central Highlands of Ethiopia. PhD Thesis, Department of Agricultural Economics, Extension and Rural Development, University of Pretoria, South Africa 